\title{
Ethnobotanical study on assessment of Practice on Traditional Plant Medicine Use among People of Wonchi District, central Ethiopia
}

\author{
Gadissa Melkamu Bulcha \\ Department of biology, Universty of Gonder, Ethiopia
}

*Corresponding Author: Gadissa Melkamu Bulcha, Department of biology, Universty of Gonder, Ethiopia.

Received date: September 13, 2021; Accepted date: October 09, 2021; Published date: October 30, 2021

Citation: Gadissa Melkamu Bulcha (2021) Ethnobotanical study on assessment of Practice on Traditional Plant Medicine Use among People of Wonchi District, central Ethiopia. J, Biotechnology and Bioprocessing 2(9); DOI: 10.31579/2766-2314/057

Copyright: (C) 2021, Gadissa Melkamu Bulcha, This is an open access article distributed under the Creative Commons Attribution License, which permits unrestricted use, distribution, and reproduction in any medium, provided the original work is properly cited.

Abstract
Ethiopia is a country characterized by a wide range of climate and ecological condition which helped to have
high diversity of medicinal plants and up to $80 \%$ of the population use traditional medicine for primary health
care. Studies on the current practices of the communities in the area are vital to document the basic information
in these regars. Therefore, this study was aimed in assessing the practices of traditional plant medicine use
among communities of Wonchi District.
Results: The most widely used route of administration in the study area was oral accounted for (56.67\%)
followed by dermal (29.63\%) This is the reason that oral and dermal routes permit rapid physiological reaction
of the prepared medicines with the pathogens and increase its curative power. The prepared traditional
medicines were applied in a number of ways, among which drinking (37.57\%), creaming (16.76\%), and eating
(10.40\%) were mentioned frequently.
Keywords: indiginous practice, local people, medicinal plants, traditional medicine, wonch district

\section{Abbreviations}

IK; indigenousknowledge, MM; modern medicine, MP; medicinalplants, TMPU; Traditional medicinal plant use

\section{Introduction}

According to WHO (1979), consultation of medicinal practitioners is very helpful for the development and incorporation of useful approaches in planning and budgeting system for health care provision of most developing nations and indigenous communities. In Africa, traditional medicine plays a central role in health care needs of rural people and urban poor. Here, it is said that, this situation would remain so long as modern medicine continues to be unable to meet the health care of the people of the continent effectively (Jansen, 1981). The value and role of this health care system will not diminish in the future, because they are both culturally viable and expected to remain affordable, while the modern health care service is both limited and expensive (WHO, 1979).

Indigenous traditional medicinal practices were carried out essentially based on private practice, i.e. private agreement between consenting parties, and the knowledge of traditional practice in most cases has descended through oral folk lore (Asfaw Debela et al., 1999). The secret information retained by traditional healers is relatively less susceptible to distortion but less accessible to the public. However, the knowledge is dynamic as the practitioners make every effort to widen their scope by reciprocal exchange of limited information with each other (Dawit Abebe, 1986).

Incomplete coverage of modern medical system, shortage of pharmaceuticals and unaffordable prices of modern drugs, make the majority of Ethiopian still to depend on traditional plant medicines (Dawit Abebe and Ahadu Ayehu, 1993; Teferi Gedif and Hahn, 2003). Hence the present study was initiated to investigate the indigenous practice of traditional plant medicine use among local communities of Wonch District, Western Ethiopia.

\section{1.Statement of the Problem}

Traditional medicine is an ancient form of health care practices long before appearance of scientific medicine which have played and continue to have important role in providing curative services to very large number of people particularly in the rural areas of almost all countries of Africa (Getachew Addis et al., 2000). It is the culture of many people because of its accessibility to the people even in most remote areas particularly in the community where care is given at low cost to patients in their home. Most people have good attitude towards traditional plant medicine, although it is not always the best form of health care system (Getachew Addis et al., 2000).

In many parts of Ethiopia, considerable numbers of researches have been done on those practice of traditional plant medicine (Aschalew Lata and Takele Etana, 2014). Like in other parts of country, in the 
current study area, the knowledge on medicinal plants depth and width become lesser and lesser due to its secrecy, unwillingness of young generation to gain the knowledge, influence of modern education, religious and awareness factors, which all results in gradual disappearance of indigenous knowledge on medicinal plants (Researcher long term direct observation). But there was no much formal research work that had been done on the indigenous practice of traditional plant medicine in the study area. Therefore, this study was aimed to document the traditional medicinal plant species practices in the study area.

\section{Materials and Method}

\subsection{Descriptions of the Study area and Location}

Wonchi District is one of the Districts in the Southwest Shoa Zone, Oromia Region, Ethiopia, which is located $124 \mathrm{~km}$ away from southwest of Addis Ababa with the area coverage of 460,516 hectare and the altitude range between $1798 \mathrm{~m}$ to $2118 \mathrm{~m}$ above sea level. The administrative center of Wonchi is Chitu and it has beautyfull Creator Lake known as Wonchi Lake from which the district has got its name. As a result many tourists from inside and outside visit this natural lake every year and it is source of income for the country (Wonch District Health Office report, 2017).

$\mathbf{N}$

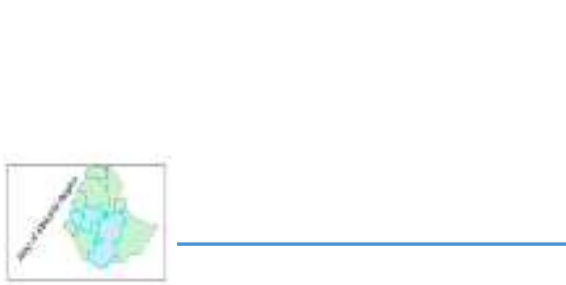

W
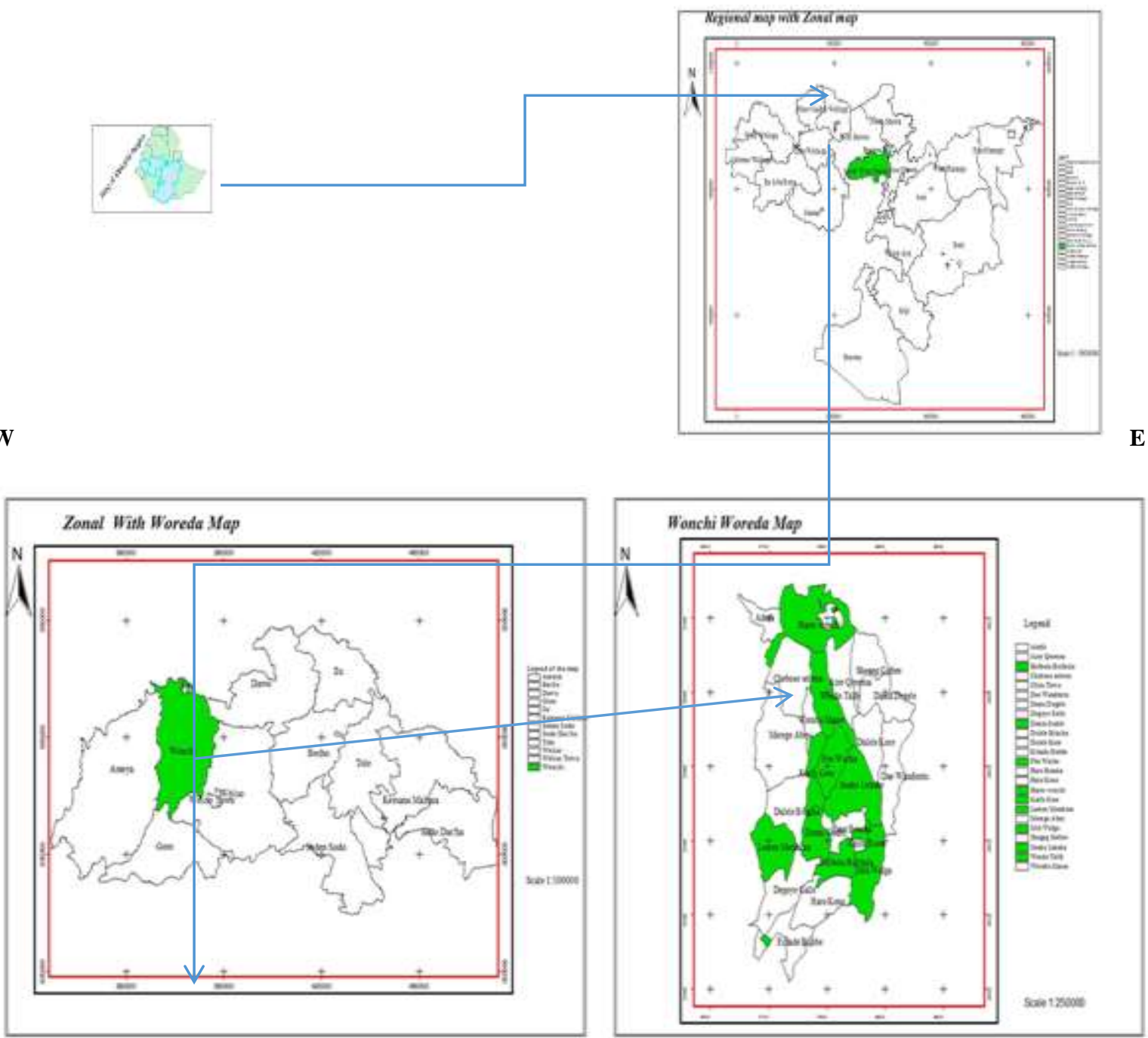

S

Figure 1: Map of the Study Area

\subsection{Population}

Demographically the district has a population of 119,736 with almost equal gender ratio of $49.8 \%$ male and $50.2 \%$ female. The average family size is 6 and the average number of children perhousehold was nearly 4 indicating that it is found to focus of development intervention addressing child wellbeing to bring real development in the 
community. Religion wise, Orthodox constitute 58.9\%, Protestants $39.6 \%$ and Muslims constitute $1.3 \%$ while the ethnic group composition, as per the Terminal evaluation findings of 2013, more than $99 \%$ are Oromo, the remaining being Amhara, Gurage and others (CSA, 2007).

\subsection{Climate}

Ecologically the district is divided in to dega or high land (40\%) and woina dega or mini land $(60 \%)$. The mean annual rain fall of the area ranges from $1650-1800 \mathrm{~mm}$ with annual temperature range of $10-30^{\circ} \mathrm{C}$ and mean average of $19.6^{\circ} \mathrm{c}$. The study area had $28.7^{\circ} \mathrm{c}$ annual mean maximum and, $19.6^{\circ} \mathrm{c}$ annual mean minimum temperature. The annual mean maximum and minimum temperature were recorded in March and November respectively. The highest rainfall distributions occur from June to September (Figure 2).

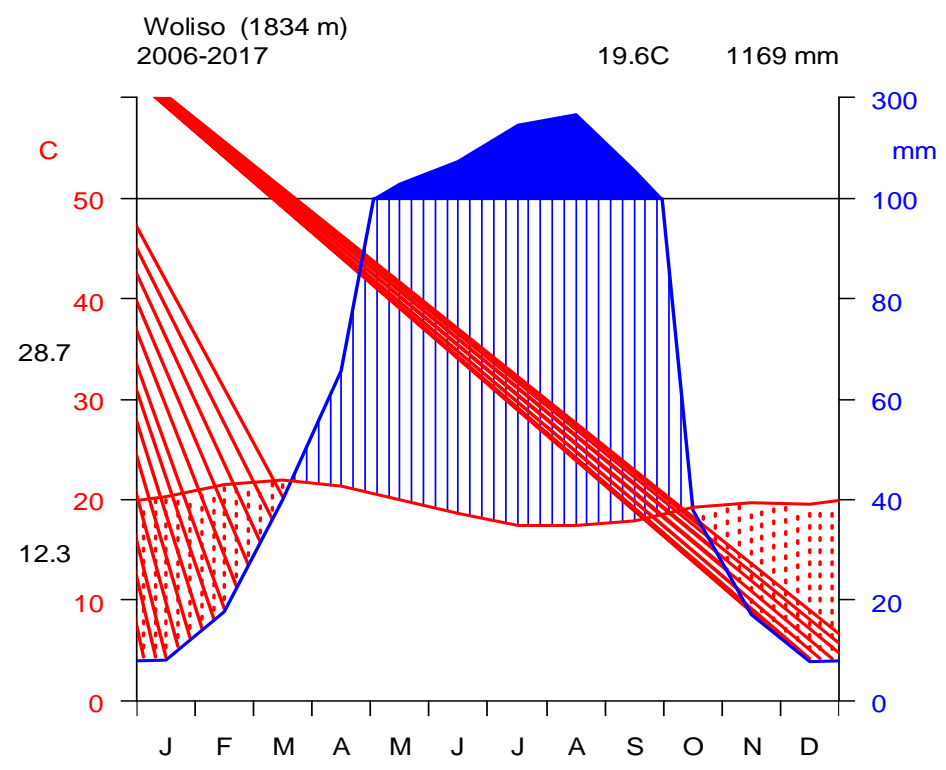

Figure 2: Climadiagram of the study area from 2006-2017

\subsection{Land use types}

Out of the total areas of the District, $82 \%$ is cultivated land, $11.7 \%$ grazing land, $8.9 \%$ covered by natural forest, $1.03 \%$ is water body while others is $18.6 \%$ (World Vision Ethiopia Wonch area Office report, 2018).

\subsection{Vegetation of the study area}

Due to variation in altitude and topographical features, the wonchi district vegetation shows three different zones, namely: Afromontane forest, sub alpine and afroalipine) vegetation (Zerihun Woldu, 1999; Puff and Sileshi Nemomissa, 2005; Getinet Masresha, 2014). The common plant species of the study area include: Achyranthes aspera, Albizia schimperiana, Alchemilla pedata, Apodytes dimidiata, Bruceaantidysenterica, Dombeya torrida, Embelia schimperi, Erica arborea,Festuca gilbertiana, Lobelia rhynchopetalum, Hagenia abyssinica, Hypericum revolutum, Jasminum abyssinicum, Juniperus procera, Kniphofia foliosa, Lobelia giberroa, Maytenus arbutifolia, Millettia ferruginea, Nuxia congesta, Olea capensis, Olea europaea subsp. caspidata, Papaneasimensis, Pittosporum viridiflorum, Prunus africana, Phytolacadodicandra, Salix subserrata, Schefflera abyssinica, Thymus schimperi and Zehneria scabra Vegetation.

\subsection{Study Design}

Field survey design was employed together information on the indigenous knowledge, attitude and practice of traditional plant medicine of the local people in the study area. During the survey, both qualitative (none numerical) and quantitative (numerical) data were collected.

\subsection{Reconnaissance Surveys}

Preliminary survey was conducted from march 20- 25, 2018. During the preliminary survey general information about the study area were gathered. Based on the information sampling technique, Sampled Kebeles, number of informants and study sites were determined.

\subsection{Study Site Selection}

From a total 23 Kebeles in the District, nine study Kebeles were selected purposively based on availability of key informants following the recommendation of government officials, stakeholders, and religious leaders during reconnaissance survey. The sampled Kebeles are (Belbela,Dimtu,Fite ,Haro wanch,Kurfo gute,Lemen meta hora,Miti welga,Sonkole kake,Waldo telfa ).

\subsection{Informant Selection}

A total of 198 informants were selected. From these 27 were key informants ( 3 informants per Kebele) which were selected purposively and 171 (19 per Kebele) of them were general informants which were selected randomly (simple random sampling technique following lottery method). Age range of informants selected for the study were from 20 to 80 who lived 5 year and above in the study area. According to storck et al. (1991) and Jarso belay (2016), the size of the sample depends on the available fund, time and other reasons and not necessarily depends on total population. 


\subsection{Data Collection Method}

Semi-structured interview, observation and guided field walks with informants were employed to obtain ethnobotanical data as used by Gidey Yirga (2010). Interview was based on a checklist of questions prepared beforehand in English and translated to local languages (Afaan Oromo). Information regarding indigenous practice of local community towards traditional plant medicine of healers was recorded at the spot. Guided field observation was made on the medinal plants to cheek the availability of the plant in the area, to know the habit and habitat of the plant. Focus group discussion was also made to get more information on medicinal plants practice

\subsection{Data Analyses}

Descriptive statistics were used to analyze the data on medicinal plants use and associated indiginous knowledge of local community, their attitude on traditional plant medicine use and medicinal plant used by traditional plant medicine healers of the study area. The results were displayed and summarized in tables and figures by using percentage, frequency and texts. The most useful information gathered on medicinal plants which were analyzed through the descriptive statistics include application, methods of preparation, route of application, disease treated, and parts used and the habit of the plant.

\section{Results and discussion}

\subsection{Socio-demographic characterstics of respondent's}

A total of 198 informants including 27 key informants were selected. As pointed out by Martin (1995), the selection of key informants is commonly systematic. Most of the respondents (77.77\%) were males (Table 1). The majority of respondent's age range was from 40$60(51.5 \%)$. Most of the participants $(86.86 \%)$ were married (Table 1$)$. Almost all religious leader respondents were followers of Orthodox Christian. From all respondents $33.83 \%$ were able to read and write. Number of farmers' respondents predominated (33.33\%) other respondents while NGO workers are lower in number (5.05\%) (Table $1)$.

\begin{tabular}{|c|c|c|c|c|}
\hline No & Variables & Response option & Frequency & Percentage $(\%)$ \\
\hline \multirow[t]{3}{*}{1.} & \multirow[t]{3}{*}{ Sex } & Male & 154 & 77.77 \\
\hline & & Female & 44 & 22.23 \\
\hline & & Total & 198 & 100 \\
\hline \multirow[t]{3}{*}{2.} & \multirow[t]{3}{*}{ Age } & $20-40$ & 14 & 7.07 \\
\hline & & $41-60$ & 102 & 51.51 \\
\hline & & $61-80$ & 82 & 41.41 \\
\hline \multirow[t]{3}{*}{3.} & \multirow[t]{3}{*}{ Marital status } & Single & 12 & 6.06 \\
\hline & & Married & 171 & 86.86 \\
\hline & & Windowed & 15 & 7.57 \\
\hline \multirow[t]{4}{*}{4.} & \multirow[t]{4}{*}{ Religion } & Christian & 142 & 71.71 \\
\hline & & Muslim & 27 & 13.63 \\
\hline & & Waqefata & 25 & 12.62 \\
\hline & & Others & 4 & 2.02 \\
\hline \multirow[t]{6}{*}{5.} & \multirow[t]{6}{*}{ Education } & Uneducated & 41 & 20.70 \\
\hline & & Able to read and write & 67 & 33.83 \\
\hline & & 12 complete & 10 & 5.05 \\
\hline & & 10 complete & 38 & 19.19 \\
\hline & & Diploma & 39 & 19.69 \\
\hline & & Degree & 3 & 1.51 \\
\hline \multirow[t]{5}{*}{6.} & \multirow[t]{5}{*}{ Occupational status. } & Farmers & 66 & 33.33 \\
\hline & & Merchants & 25 & 12.62 \\
\hline & & Government employer & 36 & 18.18 \\
\hline & & NGO worker & 10 & 5.05 \\
\hline & & Others & 61 & 30.80 \\
\hline
\end{tabular}

Table 1: Socio-demographic characteristics of respondents in the study area

\begin{tabular}{|l|l|r|r|r|r|}
\hline No & Respondents & Male & Female & Total & Percentage (\%) \\
\hline 1 & Farmers & 26 & 7 & 33 & 16.66 \\
\hline 2 & Merchants & 16 & 9 & 25 & 12.62 \\
\hline 3 & Religious leaders & 26 & 6 & 32 & 16.16 \\
\hline 4 & Health care workers & 26 & 10 & 36 & \\
\hline 5 & Traditional plant medicine users & 46 & 8 & 54 & 18.18 \\
\hline 6 & Traditional plant medicine healers & 14 & 4 & 18 & 27.27 \\
\hline 7 & Total & 154 & 44 & 198 & \\
\hline
\end{tabular}

Table 2: Distribution of informant groups by number

\subsection{Mode of preparation and route of administration}

Concerning the preparation of traditional medicine, the local people employed various methods of preparation of traditional medicines for different types of ailments. The most principal method of TMP preparation reported was in the form of crushing (20\%) and the least was cooking (1.6\%) (Table 8$)$. This might be the effective extraction of the plant gives immediate response for health problems when crushed or pounded to increase its curative potential. The result is consistent with the findings of Getnet Chekole et al. (2015) in which crushing is highly reported method of remedy preparation. But it 
disagrees with the report of Jarsso Belay (2016) which revealed that squeezing is the most used preparation method.

The most widely used route of administration was oral accounted for $(56.67 \%)$ followed by dermal $(29.63 \%)$ (Table, 8$)$. This is the reason that oral and dermal routes permit rapid physiological reaction of the prepared medicines with the pathogens and increase its curative power
(Fisseha Mesfin et al., 2009). These results are consistent with findings of various ethnobotanical researches elsewhere in Ethiopia and other countries such as that of (Mirutse Giday et al., 2003; Endalew Amenu., 2007; Haile Yinger et al., 2008; Fisseha Mesfin., etal., 2009; Behailu Etana, 2010; Ermias Lulekal and Ketema Tolossa et al., 2013; Getnet Chekole, 2015 and Patience et al., 2016).

\begin{tabular}{|l|r|r|l|r|c|}
\hline Forms of preparation & \multicolumn{1}{|l|}{ Total } & \% of total & Administration & $\begin{array}{l}\text { Remedy } \\
\text { counts }\end{array}$ & Percentage(\%) \\
\hline Crushing & 25 & 20 & Oral & 153 & 56.67 \\
\hline Pounding \& mixing & 25 & 18.4 & Dermal & 80 & 29.63 \\
\hline Pounding\&powdering & 23 & 17.6 & Nasal & 6 & 7.04 \\
\hline Squeezing & 21 & 16 & Optical & 5 & 2.22 \\
\hline Chewing & 18 & 14.4 & Auricular & 4 & 1.85 \\
\hline Pounding \& squeezing & 6 & 4 & Nasal and oral & 3 & 1.48 \\
\hline Decoction & 5 & 4 & Neck & & 1.11 \\
\hline Cooking & 2 & 1.6 & & $\mathbf{2 7 0}$ & 100 \\
\hline Total & $\mathbf{1 2 5}$ & $\mathbf{1 0 0}$ & & \\
\hline
\end{tabular}

Table 3: Mode of preparation and route of administration

\subsection{Ways of applications and dosage of plant remedies}

The prepared traditional medicines were applied in a number of ways, among which drinking (37.57\%), creaming (16.76\%), and eating $(10.40 \%)$ were mentioned frequently (Figure 6). This finding is consistent with the finding of Endalew Amenu (2007) and Behailu Etana (2010) in which drinking accounted the largest percentage of remedy.

The dosage of medicine to be administered is given by estimating age, the physical condition of the patient and the severity of the diseases. Amounts to be administered is also estimated by the use of measurements such as length of a finger (for bark, root and stem length), pinch (for powdered plant material) different measuring materials (e.g. spoon, coffee cup, tea cup and glass cups) and number count (for sap/extract drops, leaves, seeds, fruits, bulbs, rhizomes and flowers). But these measurements are not accurate enough to determine the precise amount. Some of the medicinal preparations are reported to have adverse effects on the patients. Informants reported that Hagenia abyssinica, Phytolacca dodecandra and some others are found to have adverse side effects like stomach pain, vomiting and diarrhea. The informants recommended additives for some of these adverse side effects, such as drinking of milk and barley soup immediately after intake of medicinal plants (Mirutse Giday et al., 2003; Mirutse Giday and Gobena Ameni, 2003; Kebu Balemie et al., 2004). This study agreed with study made by Abraha Teklay et al. (2013) in Kilte Awlaelo District, Eastern zone of Tigray region of Ethiopia and Getu Alemayehu (2017) in Amaro district, southern nations and nationalities of Ethiopia showed no agreement in accurate measurement or unit used among informants.

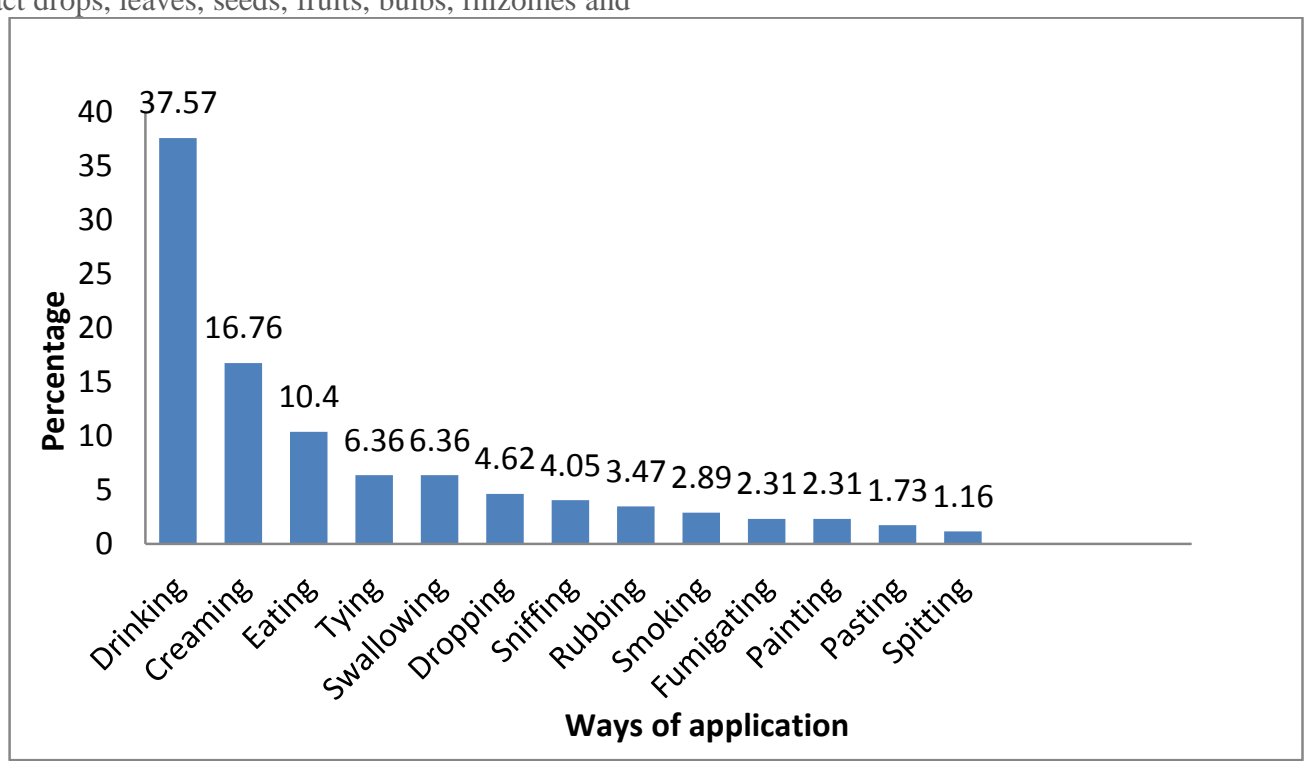

Figure 3: Application ways of remedies for human and livestock ailment treatment

\subsection{Conditions of preparation of remedies}

The results showed that majority of the remedies were prepared using fresh material $(50,53.76 \%)$, while 15 species $(16.13 \%)$ were used in the dried form and $28(30.11 \%)$ either fresh or dried. Similar studies were also conducted by Mengistu Gebrahiwot (2010) and Tadesse Beyene (2015) which showed that using fresh materials for different health problems is more than dry materials or dry or fresh. This could 
be due to the fact that the fresh materials did not lose their volatile bioactive chemicals like oils, which could deteriorate on drying.

\subsection{Disease types and related medicinal plants in the study area}

In the area a total of 57 ailement types (both human and livestock aliments) were recorded along with the medicinal plants. From these disease types, wound is the most frequently mentioned aliment type and it is claimed to be treated by many number ( 25 species) of medicinal plants. This is followed by Malaria and stomach ache which are claimed to be treated by 14 and 13 species respectively. While Abortion, back pain, bilharzia, ear defect, goiter, infertility, retained placenta and syphilis are claimed to be treated by only a single medicinal plant spcies (Appendix 7).
Paired-wise comparison analysis on six most important TMPs claimed to treat wound was performed. The result showed that Acacia abyssinica is the most usefull and effective plant to treat wound followed by Kalanchoe petitiana while Olea europaea ranked sixth. (Table 9) Preference ranking was also made on other six TMPs which were mentioned to treat malaria (Table 10). The result showed that Vernonia amygdalina is the most preferred species that ranked first followed by Juniperus procera. Eucalyptus globulus is the least preferred species followed by Lepidium sativum (Table 10). All of the species particularly thetop ranked ones by preference and pair wise needs special urgent conservation action and sustainableuses. In this regard the results agree with the findings of Behailu Etana (2010).

\begin{tabular}{|l|l|l|l|l|l|l|l|l|l|}
\hline \multirow{2}{*}{ Species name } & \multicolumn{7}{|c|}{ Respondents (1-7) } & \multirow{2}{*}{ Rank } \\
\cline { 2 - 13 } & $\mathbf{1}$ & $\mathbf{2}$ & $\mathbf{3}$ & $\mathbf{4}$ & $\mathbf{5}$ & $\mathbf{6}$ & $\mathbf{7}$ & & \\
\hline Acacia abysinica & 3 & 5 & 2 & 2 & 5 & 3 & 4 & 24 & $1^{\text {st }}$ \\
\hline Kalanchoe petitiana & 4 & 0 & 3 & 2 & 3 & 4 & 5 & 21 & $2^{\text {nd }}$ \\
\hline Asparagus africanus & 5 & 3 & 4 & 1 & 1 & 2 & 3 & 19 & $3^{\text {rd }}$ \\
\hline Euphorbia abyssinica & 2 & 4 & 1 & 4 & 0 & 3 & 2 & 16 & $4^{\text {th }}$ \\
\hline Rumex nervosus & 1 & 2 & 2 & 1 & 4 & 2 & 1 & 13 & $5^{\text {th }}$ \\
\hline Olea europaea & 0 & 1 & 3 & 5 & 2 & 1 & 0 & 12 & $6^{\text {th }}$ \\
\hline Total & 15 & 15 & 15 & 15 & 15 & 15 & 15 & 105 & \\
\hline
\end{tabular}

Table 4: Pared-wise comparsion on six more mentioned medicinsal plants against wound

\begin{tabular}{|l|l|l|l|l|l|l|l|l|l|}
\hline \multirow{2}{*}{ Species name } & \multicolumn{4}{|l|}{ Respondents } & Sum & Rank \\
\cline { 2 - 12 } & $\mathbf{1}$ & $\mathbf{2}$ & $\mathbf{3}$ & $\mathbf{4}$ & $\mathbf{5}$ & $\mathbf{6}$ & $\mathbf{7}$ & & \\
\hline Vernonia amygdalina & 6 & 2 & 4 & 5 & 1 & 2 & 6 & 26 & $1^{\text {st }}$ \\
\hline Juniperus procera & 5 & 3 & 3 & 2 & 4 & 4 & 4 & 25 & $2^{\text {nd }}$ \\
\hline Allium sativum & 4 & 6 & 5 & 1 & 2 & 3 & 3 & 24 & $3^{\text {rd }}$ \\
\hline Zingiber officinale & 3 & 5 & 4 & 2 & 6 & 1 & 2 & 23 & $4^{\text {th }}$ \\
\hline Lepidium sativum & 3 & 5 & 2 & 4 & 2 & 1 & 3 & 20 & $5^{\text {th }}$ \\
\hline Eucalyptus globulus & 2 & 4 & 1 & 3 & 5 & 1 & 2 & 18 & $6^{\text {th }}$ \\
\hline
\end{tabular}

Table 5: Preference ranking on six most frequently reported plants claimed to treat malaria

\subsection{Major human diseases in the study area}

In the study area, a total of 44 diseases of humans recorded were treated with a total of 50 plant species, where one species can treat a single disease or a number of diseases (Appendex 5). Similarly, one ailment can be treated with a combination of plant species or single plant. For example, wound is treated with 25 species of plants, malaria and stomach-ache with 14 species each; body swelling and evil eye treated with 10 species each, tonsillitis with 9 species. Fibril illness, scabies (itches) and skin rash treated with 7 species each (Appendix 5). Most of the reported medicinal plants were used to treat human ailments (Appendex 5). This showed that, the people of the study area are more knowledgeable and give great attention about human ailments as compared to livestock diseases. Similar results were recorded by Seyoum Getaneh (2009) in Debre Libanos District, North Shewa Zone of Oromia Region, Ethiopia. Medicinal plants recorded in this study also used as remedies in other part of the country. For instance, 28 species were mentioned in Mesfin Tadesse (1986), 9 species in Debela Hunde (2004), 10 species in Abiyot Berhanu (2006), 61 species in Endalew Amenu (2007), 30 plant species in Fisseha Mesfin (2009), and 59 plant species in Seyoum Getaneh (2009).

\subsection{Livestock diseases in the study area}

In comparison to human diseases, livestock diseases were treated with a few number of plant species in the study area. A total of 13 livestock ailments were identified that were treated by traditional medicinal plants in the area (Appendex 8) Common diseases affecting livestock health in the study area were bloating which was treated by 10 species, anthrax and leech by 6 species each, ectoparasite (lice) by 5 species, rabies by 3 species, erythroblasts, horse disease, retained placenta and cocoidiosis are treated by 2 species each and the remaining diseases are treated by 1 species each (Appendex 8) In addition, proper documentation and understanding of farmer's knowledge, attitude, and practices about the occurrence, cause, treatments, prevention and control of various ailments is important in designing and implementing successful livestock production (Tafesse Mesfin and Mekonen Lemma, 2001).

\subsection{Threats and conservation of medicinal plants in the study area}

\subsubsection{Threats to medicinal plants}

The causes of threats to medicinal plants in the study area were both natural and anthropogenic factors. The most dominant factors affecting the medicinal plants in the study area was agricultural land expansion (34.34\%) followed by charcoal production (16.16\%). While, the least serious factor was wild fire $(4.04 \%)$ and then overflooding $(4.54 \%)$ (Table 11$)$. Similar problems were also emphasized by Ensermu Kelbessa et al. (1992) and Vivero et al. (2005).Moreover, the problems identified so far during the course of this study are almost similar to what other literature sources studied in many parts of the country have already stated (Getachew Addis et al., 2001; Mirutse Giday et al., 2003; Tilahun Teklehymanot and Mirutse 
Giday, 2007). The medicinal plants of Wonch district in general and particular are facing the same problem.

The loss of medicinal plants associated with the missing advantages gained from medicinal plants and indiginous knowledge associated with plants (Sofowara, 1982). This is observed in wonch district as collection and search for some medicinal plants like Cordia africana, Ekebergia capensis and Thalictrum rhynchocarpum need longer time distance from their residence. Similar findings were also reported in Ethiopia (Endalew Amenu, 2007; Behailu Etana, 2010; Getnet Chekole et al., 2015) that showed need for agricultural land and for other uses severely threatened plant species in general and medicinal plants in particular.
Merchants, health care workers and other members of society obtained charcoal and timber from Acacia abyssinica and Cordia africana mature plants were recorded in the area indicating over exploitation.Balick and cox (1996) argue that quite simply, mature seed producing tree that are the backbone of the population will die and are not replaced and ultimately the resource base on which culturally values are built will disappear because of over harvesting.

Individual farmers in the area as observed during the study penetrated the forest with their axes daily. Here, the scenario is people need plants for their daily life activity i.e.as source of house hold tools, charcoal, furniture, agricultural implements. Thus, those multi-purpose species are on front line to be affected by these activities.

\begin{tabular}{|c|c|c|c|}
\hline Variable & Factors & Frequency & Percentage $(\%)$ \\
\hline \multirow{9}{*}{$\begin{array}{l}\text { Threats } \\
\text { to conservation of medicinal } \\
\text { plants }\end{array}$} & Agricultural land expansion & 68 & 34.34 \\
\hline & Fire wood & 23 & 11.61 \\
\hline & Charcoal & 32 & 16.16 \\
\hline & Timber production & 17 & 8.58 \\
\hline & Construction wood & 21 & 10.60 \\
\hline & Medicinal plant trade & 10 & 5.05 \\
\hline & Drought & 10 & 5.05 \\
\hline & Over flooding & 9 & 4.54 \\
\hline & Wild fire & 8 & 4.04 \\
\hline Total & & 198 & 100 \\
\hline
\end{tabular}

Table 6: Factors affecting Medicinal plants in the study area.

\subsection{Conservation of medicinal plants and associated knowledge in the study area}

Local people of the area know the importance of conserving the plants in both ex-situ and in-situ conservation methods. For instance, some people have started conserving the plants in fenced/protected pasture land $(18.62 \%)$; in different worship areas (churches, mosqueds) $(21.49 \%)$, in their farms (18.62\%), field/farm margins and around their home gardens $(18.58 \%)$ and live fences of the famers (20.20\%) (Table 12). Nigussie Amsalu, (2010) and Getnet Chekole, (2015) have also reported that different worship areas are conservation sites for remnant vegetation in general and medicinal plants in particular. For instance, medicinal plants like Juniperus procera, Olea europaea subsp.cuspidata and Euphorbia abyssinica are found in church forest and also plants like Hagenia abysinica, Ocimum urticifolium and Ruta chalepensis are found in the majority of home gardens in the study area, as they need these plants in their daily life as spices, medicine or for other values. Plants such as Acacia abyssinica and Cordia africana are also left as remnants of forest in the agricultural field due to their uses as timber source, for construction and fuel wood. Many medicinal plant species were also reported to be rare. Some of these local names are BOODAA WALEENSSUU(meaning plain land of Erythrina brucei), BARAA CALALQAA (meaning valley of Apodytes dimidiate), KARREE BAROODDOO (meaning hilly slope of Myrica salicifolia), and GULLUUGURRAA (meaning mountainous slop of Prunus africana). What then ethno botanists have to learn from such evidences should be the point of focus. Such local clues could be good contributors for designing ecosystem/habitat conservation, rehabilitation and resilience of species in their wild state where they are best adapted. These need an urgent attention to conserve such resources in order to optimize their use in the primary health care system. Some studies have shown that most of the medicinal plants used in Ethiopia are harvested from the wild (Mirutse Gidey, 1999; and Zemede Asfaw, 1999).

\begin{tabular}{|c|c|c|c|}
\hline Variables & & Frequency & Percentage $(\%)$ \\
\hline \multirow{2}{*}{$\begin{array}{l}\text { Knowledge } \\
\text { on the importance of } \\
\text { medicinal } \\
\text { plant conservation }\end{array}$} & Good & 101 & 51.01 \\
\hline & Not good & 97 & 48.99 \\
\hline \multirow{6}{*}{$\begin{array}{l}\text { Total } \\
\text { Types of conservation }\end{array}$} & & 198 & 100 \\
\hline & On worship areas & 42 & 21.49 \\
\hline & On protected pasture & 36 & 18.62 \\
\hline & In their farms & 43 & 21.11 \\
\hline & In home gardens & 37 & 18.58 \\
\hline & In live fences of the farmers & 40 & 20.20 \\
\hline Total & & 198 & 100 \\
\hline
\end{tabular}

Table 7: Indiginous knowledge of local community towards medicinal plants conservation 


\section{Conclusion and Recommendations}

\subsection{Conclusion}

A study on medicinal plant indiginous knowledge, attitude and practice in the area revealed that the community use medicinal plants for maintaining their primary health care. From the study it can be said that the different segment of the community in the study area are in different level of knowledge with regard to traditional plant medicine use, i.e. difference in age, sex, work and education level has impact on the knowledge of the use of traditional plant medicine. In addition from the result of the study it can be concluded that there are considerable number of community members which do have negative attitude towards use of traditional plant medicines specially educated and youngsters are developing negative attitudes. Moreover, the result of the study revealed that, though negative attitude towards traditional plant medicine is believed to be increasing from time to time, still the community is extensively practicing the use of traditional plant medicines. The ethnobotanical study of medicinal plants in the study area showed that medicinal plants are used by a large member of the population and it is the most important means of treating some common human and livestock ailments.

Most medicinal plants collected and identified were herbs and all plant parts were used for preparation of remedies. However, the use of medicinal plants for multiple purposes is leading to depletion in an alarming rate. This is worthy because of some of the uses (Agricultural expansion, firewood, construction, forage, charcoal.) are the major destructive.

Threats that erode indigenous knowledge usually comes from secrecy, oral-based knowledge transfer, the unwillingness of young generation to gain the knowledge, unavailability of the species, the influence of modern education and awareness factors are the major ones.

The results of this study also showed that cultivation of plant species in and around home gardens for different purposes have great contribution to the conservation of medicinal plants and the associated knowledge.

\subsection{Recommendations}

Based on the results of the study, the following recommendations are forwarded.

* Integrated conservation and management program on medicinal plants focused on awareness development and active involement of local community, governmental and non gevrmental bodies shall be practiced in the district.

* Young generation needs raising awareness to avoid negative impacts on the medicinal plants and associated knowledge in the area, hence, documentation of the medicinal plants of the area needs to be continued.

* Avoid uprooting of the plant species for medicinal purpose particularly before its flowering, fruiting and/seeding. If possible, it is better to use other parts of the medicinal plants such as leaves instead of root to protect them from the risk of extinction and endangering the species by collecting the roots or barks of the plants.

* Establishing traditional healers associations by providing supports like land, fund and assistances for cultivations of medicinal plants in the district would help to conserve medicinal plants.

* The societies have no good awareness with tradition plant medicine healers. So that all stakeholders should work together to change the situation and to benefit from traditional plant medicine.
* The government should create possible conditions and include to the teaching curricula about traditional plant medicine use

* To change the attitude of the society any concerned body should give trainings, seminaries about traditional plant medicine use.

* The government and other officials should recognize the use of traditional plant medicine and also the healers of traditional plant medicine need any supports from concerned bodies.

* The insights of religious institution and health care institution should be positive and work together with traditional plant medicine.

* The user's negative attitude should be changed in to positive and the lack of knowledge about traditional plant medicine use also should be changed by giving training to them and through creating awareness. All stakeholders should develop positive attitude for traditional plant medicine healers. The healers of traditional plant medicine should use appropriate measurements to give the medicine for users.

\section{Declarations}

\section{Ethical approval}

Written ethical clearance was obtained from the research and ethical committe of the department of biology university of Gonder.A formal letter was written to wonchi distict health and agricultural office and each kebele administration to conduct the study.Written informed consent was sought and obtained from every participant who decided to take part in the study. They were assured about the confidentiality of their responses.

\section{Consent for publication}

\section{Not applicable}

\section{Availablity of data and materials}

The datasets used and /or analysed during the current study available from the author for reasonable request.

\section{Completing interests}

The author declares that they have no financial and non financial competing interests.

\section{Author contributions}

GM was involved in the conception, design, analysis, interpretation, report and manuscript writing.

\section{Acknowledgements}

I extend my deepest gratitude to those who participated in the study for their time to provide relevant information.I wish to extend my thanks to data collectors and supervisors.I also indebted to all those who apply their effort in the process of this study.Finally, thankful to university of Gonder for their financial support provided.

\section{References}

1. Abebe Demissie (2001). Biodiversity conservation of medicinal plants, problems and prospects. In conservation and sustainable use of medicinal plants in Ethiopia, PP.198- 203.

2. Abiyot Berhanu, Zemede Asfaw and Ensermu Kelbessa (2006). Ethnobotany of plants used as insecticides, repellents and antimalarial agents in Jabitehnon District, West Gojjam. Ethiop. J. Sci., 29(1): 87-92.

3. Abraha Teklay, Balcha Abera and Mirutse Giday (2013). An ethnobotanical study of medicinal plants used in Kilte Awulaelo District, Tigray Region of Ethiopia. Journal of Ethnobiology and Ethnomedicine, 9:65.

4. Amare Getahun (1976). Some common medicinal and poisonous plants in Ethiopia in folk medicine. Addis Ababa University, Ethiopia. 
5. Aschalew Lata and Takele Etana (2014). Assessment of knowledge, attitude and practice on practice on traditional medicine in lag hare dire dawatown, Addisababa: Ethiopia.

6. Asfaw Debela, Dawit Abebe and Kelbessa Urga (1999). An overview of traditiona medicine in Ethiopia: Prospective and Development Efforts. In: (Tami rat Ejigu, ed.) Ethiopian.

7. Balick, m.j.and cox, P. A. (1996) plants, people and culture; Science of ethnobotany. Newyork, USA.

8. Bahailu Etana (2010). Ethnobotanical Study of Traditional Medicinal Plants of GomaWereda Jima Zone of Oromia Region, Ethiopia: M.Sc Thesis.Addis Ababa University, Addis Ababa.

9. Bannerman, R. H. (1993). Traditional Medicine and Health Care Coverage. World Health Organization, Geneva.

10. Bayaferers, T (2000). A Floristic analysis and ethno botany study of seem wet land of chefa Area, south wello, Ethiopia.M.sc.Thesis, Addis Ababa University.

11. Berhane Kidane, Vander Maesen, L.J.G., Van Andel, T. and Zemede Asfaw (2014). Ethnoveterinary medicinal plants used by the Maale and ari ethnic communities in Southern Ethiopia. Journal of Ethnopharmacology 153: 274-282.

12. Berhe, C., Mengistu, B., W/Aregay, G., (1995) Women Lead in Protecting Food Germ plasm and Herbs for Health in Ethiopia (unpublished). Report Submitted to Earth Care Africa, Nairobi, Kenya

13. Buragohain, J. (2011). Ethno medical plants used by the ethnic communities of Tinsukia district Assam, India. Recent Research in science and Technology 3(9), 31-42.

14. Cotton, C.M. (1996) Ethno botany: Principles and Applications. John Wiley and Sons Ltd., Chichester, England, pp. 347-374.

Cunningham, A.B. (1996. People, Park and Plants use recommendations for multiple use zones and development alternatives around Bwindi: Impenetrable National Park, Uganda. In: People and Plants: Working Paper 4, pp.18-25. UNESCO, Paris.

15. Daniel (1999) Biostatistics, A foundation for analysis in the health science 7th edition; New York John Wiley.

16. DawitAbebe, (1986) Traditional Medicine In Ethiopia. The attempt being made to promote it for Effective and letter utilization. SINET Ethiopian Journal of science pp., 61-69.Addis Ababa, Ethiopia.

17. Dawit and AheduAyelu. (1993). Medicinal plants and Enigmatic Health practice of Northern Ethiopian. Publishing house Addis Ababa, Ethiopia.

18. Dawit Abebeb, Asfaw Debela and KelbessaUrga (2005), Medicinal plants and other useful.

19. Dawit Abebe (1986). Traditional medicine in Ethiopia: The Attempts being made to promote it for effective and better Utilization. SINET: Ethiop. J.Sci. (Supp.): 62-69.

20. Debela Hunde, Zemede Asfaw and Ensermu Kelbessa (2004). Use and Management of Ethnoveternary Medicinal Plants by Indigenous People in Boosat, Welenchiti area. Ethiopia. J. Biol. Sci., 3 (2): 113-132.

21. Debela Hunde, MesfinTadesse and YihenewGirma.(2005) Survey of Medicinal plants used to Treated human disease in sekachekorsa, Jimma Zone, Ethiopia, J,Heath Sci.15:89-106.

22. Debela H (2001). Use and management of traditional medicinal plant by indiginous people of boosat distirct,wolencht area:An ethno botanical approach.M.SC.thesis,Addis Ababa university p.48.

23. Deilnesaw yehualawu, Haile Yeneger and TizazuGebrie (2005), ethno botanical study of Traditional medicinal plants Haramaya Ethiopia.
24. Demel Teketay (2001). Deforestation, Wood Famine and Environmental Degradation in Ethiopia's Highland Ecosystems: Urgent Need for Action. Northeast African Studies, (New Series). 8 (1): $53-76$

25. Endashaw Bekele (2007). Study on Actual Situation of Medicinal Plants in Ethiopia. Moringa stenopetala is a perennial tree.

26. Endalew Amenu (2007). Use and Management of Medicinal Plants by indigenous People of Ejaji Area (ChelyaWereda) West Shewa, Ethiopia: An Ethnobotanical Approach, M.ScThesis.Addis Ababa University, Addis Ababa.

27. Ensemu Kelbessa, Sebsebe Demissew, Zerihun Woldu and Edwards, S. (1992). Some threatened Endemic Plants of Ethiopia. In: (S. Edwards and Zemede Asfaw eds.). The Status of Some Plants in Parts of Tropical Africa. NAPRECA, Series No.2, BOTANY 200: East and Central Africa.Pp. 35-55.

28. Ermias Lulekal, Zemede Asfaw, Ensermu Kelbessa and Damme, P.V. (2013). Ethnomedicinal Study of plants used for human ailments in Ankober District, North Shewa Zone, Amhara Region, Ethiopia. Journal of Ethnobiology and Ethnomedicine 9:63.

29. Eskedar Abebe (2011). Ethno botanical study on medicinal plants used by local communities in Debark distirct, North Gondar zone, Amhara regional state.

30. Etana T (2007). Use and conservation of traditional medicinal plants by indiginous people in Gimbidistirct, westernwollega, Ethiopia,M.sc thesis,AAU,Ethiopia.

31. Fassil, H., (2003) Ethiopia: a qualitative understanding of local traditional knowledge and medicinal plant use. IK Notes 52, 1-4

32. Gedif, T., Hahn, H., (2003) The use of medicinal plants in selfcare in rural central Ethiopia. Journal of Ethnopharmacology 87, 155-161

33. Fisseha Mesfin, Sebsebe Demissew and Tilahun Teklehymanot (2009) An ethnobotanical study of medicinal plants in Wonago district, SNNPR, Ethiopia. Journal of Ethno biology and Ethno medicine 5: 28. http//www.Ethnobiomed.com/content/5/1/28. Accessed on December 26, 2018.

34. Fullas F (2001) .Ethiopian Traditional Medicine: Common Medicinal Plants in Perspective Edition. FekaduFullas: Iowa.

35. Getachew Addis, Dawit Abebe and Kelbessa Urga (2001). A Survey of Traditional Medicinal Plants in Shirka Ditrict, Arsi Zone, Ethiopia. Pharmaceutical Journal 19:30-47.

36. Getnet Chekole (2015). Ethnobotanical Study of Medicinal Plants in the environs of Tara-Gedam and Amba Remnant Forests in Libo Kemkem District. Journal of Ethnobiology and Ethnomedicine.

37. Getinet Masresha (2014). Diversity, Structure and Regeneration Status of Vegetation in Simien Mountains National Park, Northern Ethiopia: PhD. Dissertation. Addis Ababa University, Addis Ababa.

38. Getu Alemayehu (2010). Ethnobotanical Study of Medicinal Plants used by Local communities of Minjar-Shenkora District, North Shewa Zone of Amhara Region, Ethiopia. Journal of Medicinal Plants Studies, 3(6).

39. Getu Alemayehu (2017). Ethnobotanical study of plant diversity and ethnobotany of medicinal and wild edible plants in amaro district of southern nations, nationalities and peoples region and gelana district of oromia region, southern Ethiopia.

40. Haile Yineger (2005). A Study on the Ethno botany of Medicinal Plants and Floristic Composition of the dry afro Montana Forest at Bale Mountains National Park, Ethiopia: M.Sc. Thesis. Addis Ababa University, Addis Ababa.

41. Haile, Delenasaw Y. and Darnel T (2008). Ethno botanical Knowledge and Practice of the Oromo ethnic group in South 
West. International Journal of Medicine and medicinal Sciences Health spa \&Resort. Thailand.

42. Jansen, P.C.M. (1981). Spices, Condiments and Medicinal plants in Ethiopia, their Taxonomy and Agricultural Significance. Center for Agricultural Publishing and Documentation, Wageningen, Netherlands.Pp 327.

43. Jarsso Belay (2016). Ethnobotanical Study of Traditional Medicinal Plants used by Indigenous People of Jigjiga district, Somali Regional State, Ethiopia: MSc.Thesis.Haramaya University, Haramaya.

44. Kebu Balemie, Ensermu Kelbessa and Zemede Asfaw (2004). Indigenous Medicinal Plant Utilization, Management and Threats in Fentalle Area, Eastern Shewa, Ethiopia. Ethiopian Journal of Science 3 (1): 37-58.

45. Ketema Tolossa, Etana Debela, Spiridoula Athanasiadou, Adugna Tolera, Gebeyehu Ganga and Jos GM Houdijk (2013). Ethno-medicinal study of plants used for treatment of human and livestock ailments by traditional healers in South Omo, Southern Ethiopia. Journal of Ethnobiology and Ethnomedicine 9:32.

46. Konno B. (2004). International of traditional medicine with modern medicine. EHNRS. Addis Abebe.app,3-9.

47. Lai, P K., and Roy, J. (2004). Antimicrobial and chemo preventive properties of herbs and Spices. Curr. Med. Chem. 11 (11): 145160.

48. Lulekal, E., Kelbessa, E., Bekele, T., Yineger, H., (2008) An ethnobotanical study of medicinal plants in Mana Angetu District, southwestern Ethiopia. Journal of Ethnobiology and Ethnomedicine 4, 10.

49. Manandhar, N.P. (1995). A survey of medicinal plants of Jajarkot District, Nepal. Journal of Ethnopharmacology 48(1):1-6.

50. Martin, G. J. (1995). Ethnobotany: A method Manual. A 'People and Plants' Conservation Manual. Champman and Hall, London, pp. 268.

51. Mesfin Tadesse and Sebsebe Demissew (1992). Medicinal Ethiopian plants inventory, identification and classification. In: Plants used in African Traditional medicine as Practiced in Ethiopia and Uganda, East Africa. (Edwards, S. and ZemedeAsfaw, ed). Monograph Series. No. 5:1-19. Addis Ababa.

52. Mirutse G. (1999). An Ethnobotanical study of medicinal plants used by the people in Ethiopia.

53. Martin,G.J. (1995). Ethno botany: A method Manual. Chapman and Hall, London. Pp. 265 270ce. 30:18-22.

54. Mengistu Gebrehiwot (2010). An Ethnobotanical Study of Medicinal Plants in Seru district, Arsi zone of Oromia Region, Ethiopia: M.Sc. Thesis. Addis Ababa University, Addis Ababa.

55. Mesfin Tadesse (1986). Some Medicinal Plants of Central Shewa and South Western Ethiopia. SINET: Ethiop. J. Sci., 9: 143-167.

56. Mirutse Giday and Gobena Ameni (2003). An Ethnobotanical Survey on Plants of Veterinary Importance in two Woredas of Southern Tigray, Northern Ethiopia. SINET: Ethiopian J. of Sci., 26:123-136.

57. Mirutse Giday, Zemede Asfaw, Thomas Equist and Zerihun Woldu (2003) An EthnobotanicalStudy of Medicinal Plants used by the Zay people in Ethiopia. Journal of Ethnopharmacology $85: 43-52$.

58. Mulugeta Kuma (2014) Use and Management of Medicinal Plants by Indigenous People of Jima Rare District in Oromia Region, Ethiopia: M.Sc. Thesis.Haramaya University, Haramaya.

59. Mutabazi (2008).Traditional knowledge and imperialistic notion.Rabist.com, 2015.
60. Nigussie Amsalu (2010) An Ethnobotanical Study of Medicinal Plants in FartaWoreda, South Gondar Zone of Amhara Region, Ethiopia: M.Sc Thesis. Addis Ababa University, Addis Ababa.

61. Pharmacotherapy Group (2009). Current Trends in Ethnobotany. Tropical Journal of Pharmaceutical Research 8(4): 295-296.

62. Patience, T., Esezah, K., Mukadasi B., Justine N., Maud K., Patrick M. and James K. (2016). Ethnobotanical survey of medicinal plant species used by communities around Mabira Central Forest Reserve, Uganda. Journal of Ethnobiology and Ethnomedicine 12:5.

63. Quanash, N.(1998) Bicultural diversity and integrated health care in Madagascar. Nature and Resource.

64. Robert and henry, (2000) medicinal Indian $2^{\text {nd }}$ edition Asiatic publishing house.New Delhi India. Sherman, P. and Hash, GA. (2001). Why vegetable recipes are not very spicy. Evol.and $\mathrm{Hu}$ Behav.22 (3): 147-163.

65. Sebsebe Demissew and Ermias Dagne (2001). Basic and applied research on medicinal plants of Ethiopia. In: Conservation and Sustainable Use of Medicinal Plants in Ethiopia, Proceeding of The National Work Shop on Biodiversity and Sustainable use of Medicinal Plants In Ethiopia, 28 April-01 May 1998, pp 29-33. (Medhin Zewdu and Abebe Demissei eds.), IBCR, AA.

66. Seyoum Getaneh (2009). Ethnobotanical study of Medicinal Plants in Debre-Libanos district, North Shewa Zone of Oromia Region, Ethiopia M.Sc. Thesis, Addis Abeba University, pp. 94.

67. Sintayehu Tamene (2011). An Ethnobotanical Study of Medicinal Plants In Wondo Genet Natural Forest and Adjacent Kebeles, Sidama Zone, SNNP Region, Ethiopia. MSc. Thesis. Addis Ababa University, Addis Ababa, Ethiopia.

68. Sumner, J. (2000). The Natural History of Medicinal Plants. Timber Press. p. 16.

69. Stepp,J. (2004).The role of weeds as sources of pharmaceuticals. Journal of Ethno pharmacology, 92 (2-3): 163-166.

70. Sofowara, A.(1982). medicinal plants and traditional medicine in Africa. John Wiley and sons. New york,pp.225256.

71. Tadesse Beyene (2015) Ethno botany of Medicinal Plants in Erob and Gulomahda Districts, eastern Zone of Tigray Region, Ethiopia: PhD. Dissertation. Addis Ababa University, Addis Ababa.

72. Teferi Gedife and Hahn, H. (2003). The use of Medicinal Plants in self-care in rural central Ethiopia. Journal of Ethnopharmacology 87: 155-161.

73. Tena Regassa (2016). Vascular Plant Diversity and Ethnobotanical Study of Medicinal and wild edible Plants in Jibat, Gedo and Chilimo Forests, West Shewa Zone of Oromia region, Ethiopia: PhD. Dissertation. Addis Ababa University, Addis Ababa.

74. Tewodros Tesfaye (2016). Use and Management of Medicinal Plants by People of Melka Belo District, East Hararghe, Oromia Region, Ethiopia: M.Sc. Thesis.Haramaya University, Haramaya.

75. Thomas, H. (1995). Indigenous Knowledge, Emancipation and Alination. Journal of Knowledge transfer and utilization. 8(1): 63-73. University of Washington.

76. Tafesse Masfin and Mokonnen Lemma, (2001), plants in Ethiopia veterinary medicine. Their interaction with conventional drug.

77. Teferi Flatie, Teferi Gedif, Kaleab Asres and Tsige GebreMariam (2009). Ethnomedical surveyof Berta ethnic group Assosa Zone, Benishangul-Gumuz regional state, mid-west Ethiopia.J. Ethnob. and Ethnomed. 5:14

78. Tesfaye A, Zemede A (1999). An Ethno-botanical Study of the Bertha People of the Benshangul Gumuz Region in Western 
Ethiopia. Program and Abstracts of the National Workshop. "Have We ValuedOur Biodiversity?

79. Tesfaye Awas and Sebsebe Demissew (2009). Ethnobotanical study of medicinal plants in Kafficho people, southwestern Ethiopia. In: Plant Diversity in Western Ethiopia: Ecology, Ethnobotany and Conservation. The University Foundation for Student Life (Sio). University of Oslo, 2007. Norway. Pp 1-15."

80. Tesfaye Hailemariam, Sebsebe Demissew and Zemede Asfaw (2009). An ethnobotanical studyof medicinal plants used by local people in the lowlands of Konta special Wereda, Southern Nations, Nationalities and People Regional State, Ethiopia. Journal of Ethnobiology and Ethnomedicine, 6:25.

81. Tilhun Teklehaymanot and Mirutse Giday (2007). Ethnobotanical Study of Medicinal Plants used in the Zegie Peninsula, Northwestern Ethiopia. Journal of Ethnobiology and Ethno medicine. 3:12.

82. Tizazu Gebre (2005). An ethno botanical study of medicinal plants in konso special district, Southern nations, and nationalities and people's regional state, Ethiopia M.SC.Thesis.Addis Ababa University, Addis Ababa.

83. Vivero, J.L., Ensermu Kelbessa and Sebsebe Demissew (2005). The Red List of Endemic Tree \&Shrubs of Ethiopia and Eritrea. Published by Fauna and Flora International (FFI), Cambridge, UK.

84. WHO (1979) The promotion and development of traditional Medicine. World Health Organization.Technical Report Series 622, WHO, Geneva.

85. WHO (1998). Regulatory situation of herbal medicines: A World wide Review. Pp. 1-9. WHO/TRM/98.1,Geneva.
86. WHO (2002) Traditional medicine, growing needs and potetial.Geneva. ZemedeAsfaw (2001), Conservation of traditional medicinal plants.

87. $\mathrm{WHO}(2008)$

Traditionalmedicinefactsheetno.134.December,2008.http;www. who.int/mediacentr E/factessheets/fs123/en/(Accessed,

88. William, P.C. (2003) Environmental Science: Global Concern. $11^{\text {th }}$ ed. America, New York: McGraw-Hill.

89. ZemedeAsfaw (2001) The Role of Home garden in Production and Conservation of Medicinal Plants. In: Conservation and Sustainable Use of Medicinal plants in Ethiopia p. 76- 91, (Medhin Zewdu and Abebe Demissie Ed.). Proceeding of the national workshop On Biodiversity Conservation and Sustainable use of medicinal plants in Ethiopia, 28 April - 01 May 1998, IBCR, Addis Ababa.

90. Zelalem mengesha (2006) Traditional vs. modern medicine from Jimma Town south east Ethiopia: publishing house Addis Ababa Ethiopia.

91. Zewdie Kassa (2009). An ethnobotanical study of medicinal plant biodiversity of trees and Shrubs in Jeldu Wereda, Western Shoa, Ethiopia. M.Sc. Thesis Addis Ababa University, Addis Ababa.

92. Zerihun Woldu (1999). Forest in the vegetation types of Ethiopia and their status in the geographical context.In: Edwards, S., Abebe Demissie, Taye Bekele and Haase, G. (eds.). forest Genetic Resource Conservation: Principles, Strategies and Actions. Workshop proceedings. Institute of Biodiversity Conservation and Research, and GTZ, AA, $P p$ 1-41.

Appendix 1: Lists of plants collected from the study area ( $D=d r y ; F=f r e s h ; D F=d r y$ or fresh; $C l=$ climber; $H=h e r b ;$ Sh=shrub; $T=$ tree)

\begin{tabular}{|c|c|c|c|c|c|c|}
\hline No & Scientific name & Family & $\begin{array}{l}\text { Local } \\
\text { name(oromoo) }\end{array}$ & $\begin{array}{l}\text { Condition } \\
\text { of plant }\end{array}$ & Plant habitat & Habit \\
\hline 1. & Acacia abyssinica Hochst. ex Benth & Fabaceae & Girar & $\mathrm{F}$ & wild & $\mathrm{T}$ \\
\hline 2. & Achyranthesaspera L. & Amaranthaceae & Talenj & $\mathrm{F}$ & wild & $\mathrm{H}$ \\
\hline 3. & Allium cepa $\mathrm{L}$. & Alliaceae & Shinkurt Dimma & $\mathrm{F}$ & cultivated & $\mathrm{H}$ \\
\hline 4. & Allium sativum $\mathrm{L}$. & Alliaceae & Shinkurt Addii & $\mathrm{F}$ & cultivated & $\mathrm{H}$ \\
\hline 5. & Aloe pubescens Reynolds & Aloaceae & Eret & $\mathrm{F}$ & wild & $\mathrm{H}$ \\
\hline 6. & Artemisia abyssinica Sch. Bip.ex A. Ri & Asteraceae & Harit & $\mathrm{F}$ & wild & $\mathrm{H}$ \\
\hline 7. & Asparagus africanus Lam. & Asparagaceae & Yesetkest & $\mathrm{F}$ & wild & $\mathrm{Cl}$ \\
\hline 8. & Brassica carinata A.Br. & Brassicaceae & Gomenzer & $\mathrm{D}$ & cultivated & $\mathrm{H}$ \\
\hline 9. & Brassica nigra $\mathrm{L}$. & Brassicaceae & Senafich & $\mathrm{D}$ & cultivated & $\mathrm{H}$ \\
\hline 10. & Brucea antidysenterica Fresen. & Simaroubaceae & Waginos & $\mathrm{DF}$ & wild & Sh \\
\hline 11. & Buddleja polystachya Fresen. & Loganiaceae & Anfar & $\mathrm{F}$ & Both & $\mathrm{Sh}$ \\
\hline 12. & Calpurnia aurea (Ait.) Benth. & Fabaceae & Digita & DF & wild & Sh \\
\hline 13. & Capsicum annuum L. & Solanaceae & Berbere & $\mathrm{D}$ & cultivated & $\mathrm{H}$ \\
\hline 14. & Carica papaya $\mathrm{L}$. & Caricaceae & Papaya & $\mathrm{F}$ & cultivated & $\mathrm{T}$ \\
\hline 15. & Carissa spinarum $\mathrm{L}$. & Apocynaceae & Agam & DF & wild & Sh \\
\hline 16. & Citrus limon (L.) Burm.f. & Rutaceae & Lomi & $\mathrm{F}$ & cultivated & $\mathrm{Sh}$ \\
\hline 17. & Clematis simensis Fresen. & Ranunculaceae & Azo hareg & DF & wild & $\mathrm{Cl}$ \\
\hline 18. & Clerodendrum myricoides (Hochst.) Vatke & Lamiaceae & Misirich & $\mathrm{DF}$ & wild & Sh \\
\hline 19. & Clutia abyssinica Jaub. \& Spach & Euphorbiaceae & Fiyalefaj & $\mathrm{F}$ & wild & $\mathrm{H}$ \\
\hline 20. & Coffea Arabica L. & Rubiaceae & Buna & $\mathrm{D}$ & cultivated & $\mathrm{Sh}$ \\
\hline 21. & Cordia africana Lam. & Boraginaceae & Wanza & $\mathrm{D}$ & wild & $\mathrm{T}$ \\
\hline 22. & Coriandrum sativum $\mathrm{L}$. & Apiaceae & Denbelal & $\mathrm{D}$ & cultivated & $\mathrm{H}$ \\
\hline 23. & Croton macrostchyus Del. & Euphorbiaceae & Bisana & DF & wild & $\mathrm{T}$ \\
\hline
\end{tabular}




\begin{tabular}{|c|c|c|c|c|c|c|}
\hline 24. & Cucumis ficifolius A.Rich. & Cucurbitaceae & Ye medir enbuay & $\mathrm{F}$ & wild & $\mathrm{Cl}$ \\
\hline 25. & Cucurbita pepo L. & Cucurbitaceae & Duba & $\mathrm{D}$ & cultivated & $\mathrm{Cl}$ \\
\hline 26. & Cupresses lusitanica Mill. & Cupressaceae & Yeferenj tsid & $\mathrm{F}$ & Both & $\mathrm{T}$ \\
\hline 27. & Cynoglossum coeruleum(Hochst.ex.A.rich.) & Boraginaceae & Chigogit & $\mathrm{F}$ & wild & $\mathrm{H}$ \\
\hline 28. & $\begin{array}{l}\text { Cyphostemma adenocaule (Steud. exA. } \\
\text { Rich.)Des. ex Wild \&Drum. }\end{array}$ & Vitaceae & Aserkush & $\mathrm{F}$ & wild & $\mathrm{Cl}$ \\
\hline 29. & Datura stramonium L. & Solanaceae & Astanagir & $\mathrm{F}$ & wild & $\mathrm{H}$ \\
\hline 30. & Discopodium penninervum Hochst. & Solanaceae & Almit & $\mathrm{F}$ & wild & Sh \\
\hline 31. & Dodonaea angustifolia $\mathrm{L}$. & Sapindaceae & Kitkita & DF & wild & $\mathrm{Sh}$ \\
\hline 32. & Dombeya torrida (J. F. Gmel.) P. Bamps & Sterculiaceae & Wulkifa & DF & wild & $\mathrm{T}$ \\
\hline 33. & Dovyalis abyssinica (A.Rich.)Warb. & Flacourtiaceae & Koshim & $\mathrm{F}$ & Both & $\mathrm{Sh}$ \\
\hline 34. & Echinops kebericho Mesfin & Asteraceae & Kerebicho & $\mathrm{D}$ & wild & $\mathrm{H}$ \\
\hline 35. & Embelia schimperi Vatke & Myrsinaceae & Enkoko & $\mathrm{DF}$ & wild & Sh \\
\hline 36. & Erica arborea L. & Ericaceae & Asta & DF & wild & $\mathrm{T}$ \\
\hline 37. & Eucalyptus globulus Labill. & Myrtaceae & Bahirzaf Addi & DF & cultivated & $\mathrm{T}$ \\
\hline 38. & Euphorbia abyssinica. Gmel & Euphorbiacea & Kulkual & DF & wild & $\mathrm{T}$ \\
\hline 39. & Guizotia abyssinica $\mathrm{L}$. & Asteraceae & Nug & $\mathrm{D}$ & cultivated & $\mathrm{H}$ \\
\hline 40. & Hagenia abyssinica (Bruce) J. F. Gmel. & Rosaceae & Koso & $\mathrm{DF}$ & wild & $\mathrm{T}$ \\
\hline 41. & Hypericum revolutum $\mathrm{Vahl}$ & Hypericaceae & Amja & $\mathrm{DF}$ & wild & Sh \\
\hline 42. & Jasminum abyssinicum $\mathrm{L}$. & Oleaceae & Tembelel & $\mathrm{F}$ & wild & $\mathrm{Cl}$ \\
\hline 43. & Juniperus procera Endl. & Cupressaceae & Ye abesha tsid & $\mathrm{DF}$ & wild & $\mathrm{T}$ \\
\hline 44. & $\begin{array}{llll}\text { Justicia schimperiana (Hochst. exNees) } & \text { T. } \\
\text { Anders } & & & \\
\end{array}$ & Acanthaceae & Simiza sensel & $\mathrm{F}$ & wild & $\mathrm{Sh}$ \\
\hline 45. & Kalanchoe petitiana A. Rich. & Euphorbiaceae & Endawula & $\mathrm{F}$ & wild & $\mathrm{H}$ \\
\hline 46. & Kosteletzkya begonifolia Ulbr. & Malvaceae & Yemegerem & $\mathrm{F}$ & wild & $\mathrm{H}$ \\
\hline 47. & Linum usitatissimum L. & Lineaceae & Telba & $\mathrm{D}$ & cultivated & $\mathrm{H}$ \\
\hline 48. & Lobelia rhynchopetalum Hemsl. & Lobeliaceae & Jibira & $\mathrm{D}$ & wild & $\mathrm{Sh}$ \\
\hline 49. & Lepidium sativum $\mathrm{L}$. & Brassicaceae & Feto & $\mathrm{D}$ & cultivated & $\mathrm{H}$ \\
\hline 50. & Maesa lanceolata Forssk. & Myrsinaceae & Shwaria(kelawa) & $\mathrm{DF}$ & wild & $\mathrm{Sh}$ \\
\hline 51. & Melia azedarach Forssk. & Meliaceae & Nim & $\mathrm{DF}$ & cultivated & $\mathrm{T}$ \\
\hline 52. & Myrtus communis L. & Myrtaceae & Ades & $\mathrm{D}$ & wild & Sh \\
\hline 53. & Nicotiana tabacum L. & Solanaceae & Timbaho & DF & cultivated & $\mathrm{H}$ \\
\hline 54. & Nigella sativa $\mathrm{L}$. & Ranunculaceae & Tikur azmud & $\mathrm{D}$ & cultivated & $\mathrm{H}$ \\
\hline 55. & Ocimum basilicum $\mathrm{L}$. & Lamiaceae & Zikakibe & $\mathrm{F}$ & cultivate & $\mathrm{H}$ \\
\hline 56. & Ocimum lamiifolium Hochst. ex Benth. & Lamiaceae & Damakese & $\mathrm{F}$ & Both & $\mathrm{sh}$ \\
\hline 57. & $\begin{array}{l}\text { Olea europaea L. subsp. cuspidate(Wall. ex G. } \\
\text { Don) Cif. }\end{array}$ & Oleaceae & Weyra & DF & wild & $\mathrm{T}$ \\
\hline 58. & Opuntia ficus-indica (L.) Miller & Cactaceae & $\begin{array}{l}\text { Balas(Ashewa } \\
\text { kulkual) }\end{array}$ & $\mathrm{F}$ & wild & $\mathrm{Sh}$ \\
\hline 59. & Otostegia integrifolia Benth. & Lamiaceae & Tunjit & $\mathrm{D}$ & wild & $\mathrm{Sh}$ \\
\hline 60. & Osyris quadripartita Decn. & Santalaceae & Keret & $\mathrm{F}$ & wild & Sh \\
\hline 61. & Phytolacca dodecandra L' Herit. & Phytolaccaceae & Endod & $\mathrm{F}$ & wild & $\mathrm{Sh}$ \\
\hline 62. & Pittosporum viridiflorum Sims & Pittosporaceae & Tebera & $\mathrm{F}$ & wild & $\mathrm{T}$ \\
\hline 63. & Plantago lanceolata $\mathrm{L}$. & Plantaginaceae & Gortab (Wenberet) & $\mathrm{F}$ & wild & $\mathrm{H}$ \\
\hline 64. & Prunus persica (L.) Batsch & Rosaceae & Kok & $\mathrm{F}$ & cultivated & $\mathrm{T}$ \\
\hline 65. & Pterolobium stellatum (Fors)Brenan & Fabaceae & Kentafa & $\mathrm{DF}$ & wild & $\mathrm{Sh}$ \\
\hline 66. & Rhamnus prinoides L. Herit. & Rhamnaceae & Gesho & $\mathrm{F}$ & cultivated & $\mathrm{Sh}$ \\
\hline 67. & Ricinus communis L. & Euphorbiaceae & Gulo & DF & cultivated & Sh \\
\hline 68. & Rosa abyysinica Lindley & Rosaceae & Kega & $\mathrm{F}$ & wild & $\mathrm{Sh}$ \\
\hline 69. & Rumex abyssinicus Jacq. & Polygonaceae & Makmako & $\mathrm{DF}$ & wild & $\mathrm{H}$ \\
\hline 70. & Rumex nepalensis Spreng. & Polygonaceae & Lut & $\mathrm{F}$ & wild & $\mathrm{H}$ \\
\hline 71. & Rumex nervosus Vahl & Polygonaceae & Embacho & DF & wild & $\mathrm{Sh}$ \\
\hline 72. & Ruta chalepensis L. & Rutaceae & Tenadam & $\mathrm{DF}$ & cultivated & $\mathrm{H}$ \\
\hline 73. & Salix macronata Thunb. & Salicaceae & Lahaya & $\mathrm{F}$ & wild & $\mathrm{T}$ \\
\hline
\end{tabular}




\begin{tabular}{|c|c|c|c|c|c|c|}
\hline 74. & Schinus molle L. & Anacardiaceae & Kundoberbere & $\mathrm{DF}$ & cultivated & $\mathrm{T}$ \\
\hline 75. & Sesamum indicum L. & Pedaliaceae & Selit & $\mathrm{D}$ & cultivated & $\mathrm{H}$ \\
\hline 76. & Sida schimperiana Hochst. Ex A. Rich. & Malvaceae & Cifrig & $\mathrm{DF}$ & wild & $\mathrm{H}$ \\
\hline 77. & Solanum adoense (Hochst) ex A. Rich. & Solanaceae & Zerch Enbuay & $\mathrm{DF}$ & wild & $\mathrm{Sh}$ \\
\hline 78. & Solanum incanum L. & Solanaceae & Enbuay & $\mathrm{DF}$ & wild & $\mathrm{Sh}$ \\
\hline 79. & Solanecio gigas (Vatke.)C. Jeffery & Asteraceae & $\begin{array}{l}\text { Yeshikoko gomen } \\
\text { (Mogne qitel) }\end{array}$ & $\mathrm{F}$ & wild & $\mathrm{Sh}$ \\
\hline 80. & Stephania abyssinica(Dillo\&A.Rich.)Walp. & Menispermacae & $\begin{array}{l}\text { Ye ayit hareg } \\
\text { (Chewchawit) }\end{array}$ & $\mathrm{F}$ & wild & $\mathrm{Cl}$ \\
\hline 81. & Syzgium aromaticum L. & Myrtaceae & Kirunfu & $\mathrm{D}$ & cultivated & $\mathrm{T}$ \\
\hline 82. & Tanacetum cinerariifolium (Trev). Sch. Bip. & Asteraceae & Kaba & $\mathrm{F}$ & wild & $\mathrm{H}$ \\
\hline 83. & Trigonella foenum-Graecum L. & Fabaceae & Abish & $\mathrm{D}$ & cultivated & $\mathrm{H}$ \\
\hline 84. & Thymus schimperi Ronniger & Lamiaceae & Tosign & $\mathrm{DF}$ & wild & $\mathrm{H}$ \\
\hline 85. & Urera hypselodendron (A. Rich.) Wedd. & Urticaceae & Lankuso & $\mathrm{F}$ & wild & $\mathrm{Cl}$ \\
\hline 87. & Verbena officinalis L. & Verbenaceae & Atuch & $\mathrm{F}$ & wild & $\mathrm{H}$ \\
\hline 88. & Verbascum sinaiticum Benth. & Scrophulariaceae & Kutina(ye Ahya joro) & $\mathrm{DF}$ & wild & $\mathrm{H}$ \\
\hline 89. & Vernonia amygdalina Del. & Asteraceae & Gerawa & $\mathrm{F}$ & Both & $\mathrm{T}$ \\
\hline 90. & Vernonia hymenolepis A.Rich. & Asteraceae & Weynagift & $\mathrm{F}$ & & $\mathrm{Sh}$ \\
\hline 91. & Zehneria scabra (Linn.f.) Sond. & Cucurbitaceae & $\begin{array}{l}\text { Haregresa(Etse } \\
\text { sabeq(NechHareg) }\end{array}$ & $\mathrm{F}$ & wild & $\mathrm{Cl}$ \\
\hline 92. & Zingiber officinale Roscoe & Zingiberaceae & Jinjible & $\mathrm{F}$ & cultivated & $\mathrm{H}$ \\
\hline 93. & Ziziphus spina- christi (L.) Desf. & Rhamnaceae & Gaba & $\mathrm{F}$ & Both & $\mathrm{Sh}$ \\
\hline
\end{tabular}


Appendix 2: List of medicinal plants used for both human ( $\mathrm{Hu}$ ) and livestock (Li) ailment treatment: scientific name; family; local name (A=Amharic; O=Afan Oromo) habit; parts used; disease treated; methods of preparation with dosage used and route of application.

Key:Habit (Ha.): Herb (H) ;Shrub (Sh) ; Tree(T); Climber (Cl.); Epiphyte (Ep.); Parts used (Bark, B; Latex, La; Root, R; Leaf, L; Fruit, Fu.; Flower, Fw.; Seed, Se.;Stem,St.;Sap,Sa; Bulb, Bu.; Root and leaf, LR.; Above ground, Ag; Leaf and seed, LSe; shoot, Sht.

\begin{tabular}{|c|c|c|c|c|c|c|c|c|}
\hline Scientific name & Family & $\begin{array}{l}\text { Local } \\
\text { Name }\end{array}$ & Ha & $\mathbf{P u}$ & $\begin{array}{l}\text { Used } \\
\text { for }\end{array}$ & Disease treated & Mode of preparation & Route \\
\hline \multirow{2}{*}{$\begin{array}{l}\text { Acacia abyssinica } \\
\text { Hochst. ex Benth. }\end{array}$} & \multirow[t]{2}{*}{ Fabaceae } & \multirow{2}{*}{$\begin{array}{l}\text { Girar }(A) \\
\text { Laaftoo(O) }\end{array}$} & \multirow[t]{2}{*}{$\mathrm{T}$} & Sht & $\mathrm{Hu}$ & Tonsillitis & Fresh shoot is chewed and the juice is swallowed. & Oral \\
\hline & & & & Sht & $\mathrm{Hu}$ & Wound & $\begin{array}{l}\text { Fresh shoot is pounded, squeezed and the sap is creamed on } \\
\text { affected part }\end{array}$ & Dermal \\
\hline \multirow[t]{5}{*}{ Achyranthes aspera $\mathrm{L}$. } & \multirow[t]{5}{*}{$\begin{array}{l}\text { Amaranthacea } \\
\text { e }\end{array}$} & \multirow[t]{5}{*}{$\begin{array}{l}\text { Talenj(A) } \\
\operatorname{Darguu}(\mathrm{O})\end{array}$} & \multirow[t]{5}{*}{$\mathrm{H}$} & $\mathrm{L}$ & Both & Pneumonia & $\begin{array}{l}\text { Fresh leaf are pounded, mixed with water and drunk in the } \\
\text { Morning. }\end{array}$ & Oral \\
\hline & & & & $\mathrm{L}$ & $\mathrm{Hu}$ & Body swelling & Leaf is squeezed and creamed on swollen body. & Dermal \\
\hline & & & & $\mathrm{L}$ & $\mathrm{Hu}$ & Wound & Leaves are pounded and tied on the wound. & Dermal \\
\hline & & & & $\mathrm{L}$ & $\mathrm{Hu}$ & Nasal bleeding & $\begin{array}{l}\text { Fresh leaf of Achyranthes aspera is squeezed and its juice is } \\
\text { dropped in to the nostrils to stop bleeding. }\end{array}$ & Dermal \\
\hline & & & & $\mathrm{R}$ & $\mathrm{Hu}$ & Stomach-ache & $\begin{array}{l}\text { The root of Achyranthes aspera is chewed and swallowed during } \\
\text { feeling of ache. }\end{array}$ & Oral \\
\hline \multirow[t]{2}{*}{ Allium cepa $\mathrm{L}$. } & \multirow[t]{2}{*}{ Alliaceae } & \multirow{2}{*}{$\begin{array}{l}\text { Qey } \\
\text { shenkurt(A) } \\
\text { Qullubbii } \\
\text { Diimaa(O) }\end{array}$} & \multirow[t]{2}{*}{$\mathrm{H}$} & \multirow[t]{2}{*}{$\mathrm{Bu}$} & $\mathrm{Li}$ & Leech & $\begin{array}{l}\text { Fresh bulb is pounded, mixed with little water, decanted and } \\
\text { poured through the nose. }\end{array}$ & Oral \\
\hline & & & & & $\mathrm{Hu}$ & Asthma & $\begin{array}{l}\text { Fresh bulb of Allium cepa is crushed with Zingiber officinale } \\
\text { rhizome and boiled. Then drink the solution in the morning until } \\
\text { recovery. }\end{array}$ & Oral \\
\hline \multirow[t]{3}{*}{ Allium sativum L. } & \multirow[t]{3}{*}{ Alliaceae } & \multirow{3}{*}{$\begin{array}{l}\text { Nech } \\
\text { shinkurt(A) } \\
\text { Qullubbii } \\
\text { adii(O) }\end{array}$} & \multirow[t]{3}{*}{$\mathrm{H}$} & $\mathrm{Bu}$ & $\mathrm{Hu}$ & Malaria & $\begin{array}{l}\text { Fresh bulb of Allium sativum and rhizome of Zinger officinale are } \\
\text { pounded together, mixed with honey and eaten. }\end{array}$ & Oral \\
\hline & & & & $\mathrm{Bu}$ & $\mathrm{Hu}$ & Evil eye & $\begin{array}{l}\text { Bulb of Allium sativum is crushed together with rhizome of } \\
\text { Zingiber officinale and Lepidium sativum, pasted with honey and } \\
2 \text { tea spoons is taken. }\end{array}$ & Oral \\
\hline & & & & $\mathrm{Bu}$ & $\mathrm{Hu}$ & Colds & $\begin{array}{l}\text { The Bulb is pounded, mixed with honey and } 2-3 \text { teaspoon is eaten } \\
\text { every day for three days. }\end{array}$ & Oral \\
\hline \multirow[t]{3}{*}{$\begin{array}{l}\text { Aloe pubescens } \\
\text { Reynolds }\end{array}$} & \multirow[t]{3}{*}{ Aloaceae } & \multirow[t]{3}{*}{$\begin{array}{l}\text { Eret }(\mathrm{A}) \\
\text { Argiisa(O) }\end{array}$} & \multirow[t]{3}{*}{$\mathrm{H}$} & $\mathrm{La}$ & $\mathrm{Hu}$ & Fire burn & The latex is painted on the wound & Dermal \\
\hline & & & & $\mathrm{La}$ & $\mathrm{Hu}$ & Ringworm & $\begin{array}{l}\text { The latex of the young leaves is creamed on the affected area and } \\
\text { repeated every day until recovery. }\end{array}$ & Dermal \\
\hline & & & & $\mathrm{La}$ & $\mathrm{Li}$ & anthrax & $\begin{array}{l}\text { Root of Aloe pubescens is crushed and mixed with cold water. } \\
\text { Then two cup of tella is given to cattle. }\end{array}$ & Oral \\
\hline \multirow[t]{3}{*}{$\begin{array}{l}\text { Artemisia abyssinica } \\
\text { Sch. Bip.ex A. Rich. }\end{array}$} & \multirow[t]{3}{*}{ Asteraceae } & \multirow[t]{3}{*}{$\begin{array}{l}\text { Harit(A) } \\
\text { Harrittaa(O) }\end{array}$} & \multirow[t]{3}{*}{$\mathrm{H}$} & $\mathrm{L}$ & $\mathrm{Hu}$ & Evil eye & $\begin{array}{l}\text { Leaf concoction together with root of Echinops kebericho is added } \\
\text { to a burning fire and smoked to the patient. }\end{array}$ & Nasal \\
\hline & & & & $\mathrm{L}$ & $\mathrm{Hu}$ & Malaria & $\begin{array}{l}\text { Fresh leaf is crushed and pounded with water, filtered and drunk } \\
\text { until recovery. }\end{array}$ & Oral \\
\hline & & & & $\mathrm{L}$ & $\mathrm{Hu}$ & $\begin{array}{l}\text { Child } \\
\text { Stomach-ache }\end{array}$ & Leaf is squeezed and $1 / 4$ of coffee cup juice is given to children & Oral \\
\hline
\end{tabular}




\begin{tabular}{|c|c|c|c|c|c|c|c|c|}
\hline \multirow[t]{4}{*}{$\begin{array}{l}\text { Asparagus africanus } \\
\text { Lam. }\end{array}$} & \multirow[t]{4}{*}{ Asparagaceae } & \multirow[t]{4}{*}{$\begin{array}{l}\text { Yesetkest(A) } \\
\text { Sariitii }(O)\end{array}$} & \multirow[t]{4}{*}{$\mathrm{Cl}$} & $\mathrm{R}$ & $\mathrm{Hu}$ & $\begin{array}{l}\text { Retained } \\
\text { placenta }\end{array}$ & $\begin{array}{l}\text { Fresh root is pounded; mixed with water and boiled, decanted, } \\
\text { mixed with honey and drunk. }\end{array}$ & Oral \\
\hline & & & & $\mathrm{R}$ & $\mathrm{Hu}$ & Wound & $\begin{array}{l}\text { Fresh root is pounded together with leaves of Dodonea } \\
\text { angustifolia, mixed with butter and creamed on the wound. }\end{array}$ & Dermal \\
\hline & & & & $\mathrm{L}$ & $\mathrm{Hu}$ & Malaria & $\begin{array}{l}\text { Leaf is smashed, mixed with water and decanted, then mixed with } \\
\text { milk and one coffee cup is taken every morning. }\end{array}$ & Oral \\
\hline & & & & $\mathrm{L}$ & $\mathrm{Li}$ & Bloating & $\begin{array}{l}\text { Leaves of Asparagus africanus\& the root of Verbasicum } \\
\text { sinaiticum are pounded and mixed with water, decanted and } \\
\text { dropped in to left nostril. }\end{array}$ & Nasal \\
\hline \multirow[t]{2}{*}{$\begin{array}{l}\text { Brassica } \\
\text { A.Br. }\end{array}$} & \multirow[t]{2}{*}{ Brassicaceae } & \multirow[t]{2}{*}{$\begin{array}{l}\text { Gomenzer }(\mathrm{A}) \\
\mathrm{Ija} \operatorname{raafuu}(\mathrm{O})\end{array}$} & \multirow[t]{2}{*}{$\mathrm{H}$} & $\mathrm{Se}$ & $\mathrm{Hu}$ & $\begin{array}{l}\text { Stomach } \\
\text { problem }\end{array}$ & Crushed and eaten with Allium sativum by adding salt. & Oral \\
\hline & & & & $\mathrm{Se}$ & $\mathrm{Hu}$ & Cancer & $\begin{array}{l}\text { The seed of Brassica carinata together with seed of Ricinus } \\
\text { communis is crushed, powdered and mixed with honey and then } \\
\text { creamed on affected part. }\end{array}$ & Dermal \\
\hline \multirow[t]{2}{*}{ Brassica nigra $\mathrm{L}$. } & \multirow[t]{2}{*}{ Brassicaceae } & \multirow[t]{2}{*}{$\begin{array}{l}\text { Senafich }(\mathrm{A}) \\
\text { Sanaafica }(\mathrm{O})\end{array}$} & \multirow[t]{2}{*}{$\mathrm{H}$} & $\mathrm{Se}$ & $\mathrm{Hu}$ & Malaria & $\begin{array}{l}\text { Powdered seed of Brassica nigra, chopped Allium sativum and } \\
\text { Cicer arietinum seed ( } \\
\text { Shimbura) are soaked with water and eaten after one day by enjera } \\
\text { in the morning. }\end{array}$ & Oral \\
\hline & & & & $\mathrm{Se}$ & $\mathrm{Hu}$ & $\begin{array}{l}\text { Intestinal } \\
\text { parasites } \\
\text { Amoeba }\end{array}$ & $\begin{array}{l}\text { The semi-liquid condiment made of Brassica nigra called (awaze) } \\
\text { is eaten with either injera or germinated bean seeds. }\end{array}$ & \\
\hline \multirow[t]{4}{*}{$\begin{array}{l}\text { Brucea antidysenterica } \\
\text { Fresen. }\end{array}$} & \multirow[t]{4}{*}{$\begin{array}{l}\text { Simaroubacea } \\
\text { e }\end{array}$} & \multirow{4}{*}{$\begin{array}{l}\text { Waginos } \\
\text { (Abalo(A) } \\
\text { Qomanyoo } \\
\text { (O) }\end{array}$} & \multirow[t]{4}{*}{ Sh } & $\mathrm{L}$ & $\mathrm{Li}$ & $\begin{array}{l}\text { External } \\
\text { parasites (lice) }\end{array}$ & $\begin{array}{l}\text { Leaf of Brucea antidysenterica is pounded and mixed with water. } \\
\text { The mixture is used to wash skin of cattle, donkey, mule and horse. }\end{array}$ & Dermal \\
\hline & & & & $\mathrm{L}$ & $\mathrm{Hu}$ & $\begin{array}{l}\text { Wound } \\
\text { and itches }\end{array}$ & $\begin{array}{l}\text { Dried leaf of Brucea antidysenterica is pounded, mixed with } \\
\text { butter and creamed the affected part until recovery. }\end{array}$ & Dermal \\
\hline & & & & $\mathrm{R}$ & $\mathrm{Hu}$ & Evil eye & $\begin{array}{l}\text { Dried root of Brucea antidysenterica and Carissa spinarum are } \\
\text { mixed together, smoked \& inhaled. }\end{array}$ & Nasal \\
\hline & & & & $\mathrm{Se}$ & $\mathrm{Hu}$ & Back pain & $\begin{array}{l}\text { Seed of Brucea antidysenterica is boiled with milk and drunk for } \\
3-4 \text { consecutive days. }\end{array}$ & Oral \\
\hline \multirow[t]{2}{*}{$\begin{array}{l}\text { Buddleja polystachya } \\
\text { Fresen. }\end{array}$} & \multirow[t]{2}{*}{ Loganiaceae } & \multirow{2}{*}{$\begin{array}{l}\text { Anfar( A) } \\
\text { Adaaddii }(\mathrm{O}) \\
\text { Hanfaaree }(\mathrm{O})\end{array}$} & \multirow[t]{2}{*}{ Sh } & $\mathrm{L}$ & $\mathrm{Li}$ & Eye disease & $\begin{array}{l}\text { Fresh Leaf of Buddleja polystachya is chewed and spitted on cattle } \\
\text { eye. }\end{array}$ & Eye \\
\hline & & & & $\mathrm{L}$ & $\mathrm{Hu}$ & Wound & $\begin{array}{l}\text { Fresh leaf of Buddleja Polystachya is pounded, powdered and } \\
\text { applied on wound }\end{array}$ & Dermal \\
\hline \multirow[t]{3}{*}{$\begin{array}{l}\text { Calpurnia aurea (Ait.) } \\
\text { Benth. }\end{array}$} & \multirow[t]{3}{*}{ Fabaceae } & \multirow[t]{3}{*}{$\begin{array}{l}\text { Digita(A) } \\
\text { Ceekaa }(\mathrm{O})\end{array}$} & \multirow[t]{3}{*}{ Sh } & $\mathrm{L}$ & $\mathrm{Hu}$ & Wound & $\begin{array}{l}\text { Dried leaf of Calpurnia aurea is pounded, mixed with butter or } \\
\text { honey and creamed on the wounded part. }\end{array}$ & Dermal \\
\hline & & & & $\mathrm{L}$ & $\mathrm{Li}$ & Scabies and Lice & $\begin{array}{l}\text { Leaf of Calpurnia aurea, Croton macrostachyus and Justicia } \\
\text { schimperiana are pounded, mixed with water and wash the body } \\
\text { of the cattle every morning until the Scabies (itches) and parasites } \\
\text { are eradicated. }\end{array}$ & Dermal \\
\hline & & & & $\mathrm{L}$ & Both & Snake bite & $\begin{array}{l}\text { Leaf of Calpurnia aurea is squeezed and drop of the sap is given } \\
\text { orally to cattle and to Human. }\end{array}$ & Oral \\
\hline
\end{tabular}




\begin{tabular}{|c|c|c|c|c|c|c|c|c|}
\hline & & & & $\mathrm{L}$ & $\mathrm{Hu}$ & Diarrhea & $\begin{array}{l}\text { Fresh leaf of Calpurnia aurea is squeezed and the juice is drunk } \\
\text { before breakfast. }\end{array}$ & Oral \\
\hline \multirow[t]{2}{*}{$\begin{array}{l}\text { Capsicum } \\
\text { Annuum L. }\end{array}$} & \multirow[t]{2}{*}{ Solanaceae } & \multirow[t]{2}{*}{$\begin{array}{l}\text { Berbere (A) } \\
\text { Qaaraa }(O)\end{array}$} & \multirow[t]{2}{*}{$\mathrm{H}$} & \multirow[t]{2}{*}{$\begin{array}{l}\mathrm{Fu} / \mathrm{S} \\
\mathrm{e}\end{array}$} & $\mathrm{Hu}$ & Skin rash & $\begin{array}{l}\text { Fruit and seed of Capsicum annuumis pounded, powdered, mixed } \\
\text { withbutter and creamed the infectedparts }\end{array}$ & Dermal \\
\hline & & & & & $\mathrm{Hu}$ & Tonsillitis & $\begin{array}{l}\text { Fruit and seed of Capsicum annuumis pounded, powdered, mixed } \\
\text { withoil, roasted and drunk }\end{array}$ & Oral \\
\hline \multirow[t]{3}{*}{ Carica papaya $\mathrm{L}$. } & \multirow[t]{3}{*}{ Caricaceae } & \multirow{3}{*}{$\begin{array}{l}\text { Papaya }(\mathrm{A}) \\
\text { Pappayya }(\mathrm{O})\end{array}$} & \multirow[t]{3}{*}{$\mathrm{T}$} & $\mathrm{Fu}$ & $\mathrm{Hu}$ & Heart problem & Fruit is eaten & Oral \\
\hline & & & & $\mathrm{L}$ & $\mathrm{Hu}$ & malaria & $\begin{array}{l}\text { Leaf of Carica papaya and Allium sativum bulb are pounded } \\
\text { together and made in the form of soup, boiled and mixed with } \\
\text { honey and two cup are drunk. }\end{array}$ & Oral \\
\hline & & & & $\mathrm{L}$ & $\mathrm{Hu}$ & $\begin{array}{l}\text { Intestinal } \\
\text { parasites }\end{array}$ & $\begin{array}{l}\text { Fresh leaves are boiled with water and cooled then drunk in the } \\
\text { morning. }\end{array}$ & Oral \\
\hline \multirow[t]{4}{*}{ Carissa spinarum L. } & \multirow[t]{4}{*}{ Apocynaceae } & \multirow[t]{4}{*}{$\begin{array}{l}\operatorname{Agam}(\mathrm{A}) \\
\operatorname{Agamsa}(\mathrm{O})\end{array}$} & \multirow[t]{4}{*}{ Sh } & $\mathrm{R}$ & $\mathrm{Hu}$ & Evil eye & $\begin{array}{l}\text { Root of Asparagus africanus, root, Lobelia rhynchopetalum bark, } \\
\text { Artemisia abyssinica root and leaf, Allium sativum and Ruta } \\
\text { chalepensis are crushed and smashed together and rolled by piece } \\
\text { of cloth and tied on neck or arm. }\end{array}$ & Neck \\
\hline & & & & $\mathrm{L}$ & $\mathrm{Hu}$ & Head ache & $\begin{array}{l}\text { Dried Leaf of Carissa spinarum is pounded and the smoke is used } \\
\text { as treatment for head ache. }\end{array}$ & Nasal \\
\hline & & & & $\mathrm{L}$ & $\mathrm{Hu}$ & Stomach-ache & $\begin{array}{l}\text { Leaf of Carissa spinarum is Pounded, mixed with honey. Two- } \\
\text { three spoon is taken early in the morning before breakfast. }\end{array}$ & Oral \\
\hline & & & & $\mathrm{L}$ & $\mathrm{Hu}$ & Malaria & $\begin{array}{l}\text { Fresh root is pounded, mixed with cold water, decanted and drunk } \\
\text { after one day. }\end{array}$ & Oral \\
\hline \multirow[t]{4}{*}{$\begin{array}{lll}\text { Citrus limon } & \text { (L.) } \\
\text { Burm.f. } & & \\
\end{array}$} & \multirow[t]{4}{*}{ Rutaceae } & \multirow[t]{4}{*}{$\begin{array}{l}\text { Lomi (A) } \\
\text { Loomii }(\mathrm{O})\end{array}$} & \multirow[t]{4}{*}{ Sh } & $\mathrm{L}$ & $\mathrm{Hu}$ & Cough & $\begin{array}{l}\text { The leaf of Citrus limon is pounded, powdered, mixed with milk, } \\
\text { boiled and sugar is added. Then drink pure liquid during feeling } \\
\text { of the pain. }\end{array}$ & Oral \\
\hline & & & & $\mathrm{Fu}$ & $\mathrm{Hu}$ & Athlete's foot & $\begin{array}{l}\text { Fruit of Citrus limon is squeezed and creamed on affected part for } \\
\text { continuous days. }\end{array}$ & Dermal \\
\hline & & & & $\mathrm{Fu}$ & $\mathrm{Hu}$ & Scabies(itches) & Fruit juice is squeezed and applied to the affected part. & Dermal \\
\hline & & & & $\mathrm{Fu}$ & $\mathrm{Hu}$ & Vomit & Fresh fruits are squeezed and the juice is drunk & Oral \\
\hline \multirow[t]{4}{*}{$\begin{array}{l}\text { Clematis simensis } \\
\text { Fresen. }\end{array}$} & \multirow[t]{4}{*}{$\begin{array}{l}\text { Ranunculacea } \\
\text { e }\end{array}$} & \multirow{4}{*}{$\begin{array}{l}\text { Azo hareg(A) } \\
\text { Hidda } \\
\text { feetii }(\mathrm{O})\end{array}$} & \multirow[t]{4}{*}{$\mathrm{Cl}$} & $\mathrm{L}$ & $\mathrm{Hu}$ & Cancer & $\begin{array}{l}\text { Fresh leaf is crushed, smashed, rolled by clean cloth and tied on } \\
\text { hand. }\end{array}$ & Dermal \\
\hline & & & & & $\mathrm{Li}$ & Horse itch & Leaf of Clematis simensis is squeezed and dropped on itched part. & Dermal \\
\hline & & & & $\mathrm{R} / \mathrm{L}$ & $\mathrm{Hu}$ & Tonsillitis & $\begin{array}{l}\text { Leaf of Clematis simensis is crushed, rolled in clean cloth and tied } \\
\text { on neck. }\end{array}$ & Neck \\
\hline & & & & $\mathrm{R} / \mathrm{L}$ & $\mathrm{Hu}$ & Wound & $\begin{array}{l}\text { Dried root and leaf of Clematis simensis are pounded, powdered, } \\
\text { mixed with butter and creamed on affected part. }\end{array}$ & Dermal \\
\hline \multirow[t]{4}{*}{$\begin{array}{l}\text { Clerodendrum } \\
\text { myricoides (Hochst.) } \\
\text { Vatke }\end{array}$} & \multirow[t]{4}{*}{ Lamiaceae } & \multirow[t]{4}{*}{$\begin{array}{l}\text { Misirich }(\mathrm{A}) \\
\text { Maraasisaa }(\mathrm{O}\end{array}$} & \multirow[t]{4}{*}{ Sh } & $\mathrm{R}$ & $\mathrm{Hu}$ & Stomach-ache & $\begin{array}{l}\text { Root of Clerodendrum myricoides, fruit of Croton macrostchyus } \\
\text { and root of Solanum adoense are crushed together and mixed with } \\
\text { rotten butter and drunk. }\end{array}$ & Oral \\
\hline & & & & $\mathrm{R}$ & $\mathrm{Hu}$ & Headache & $\begin{array}{l}\text { Root latex of Clerodendrum myricoides is dried, powdered, mixed } \\
\text { with butter and creamed on head }\end{array}$ & Dermal \\
\hline & & & & $\mathrm{R}$ & $\mathrm{Hu}$ & Evil eye & $\begin{array}{l}\text { Dried root is crushed and put on broken pot, and then fire is added } \\
\text { to it and fumigated. }\end{array}$ & Nasal \\
\hline & & & & $\mathrm{L}$ & $\mathrm{Hu}$ & Eye problems & Leaves are pounded and powdered then sprayed to the eye. & Eye \\
\hline
\end{tabular}




\begin{tabular}{|c|c|c|c|c|c|c|c|c|}
\hline \multirow[t]{3}{*}{$\begin{array}{l}\text { Clutia abyssinica Jaub. } \\
\text { \& Spach }\end{array}$} & \multirow[t]{3}{*}{$\begin{array}{l}\text { Euphorbiacea } \\
\text { e }\end{array}$} & \multirow[t]{3}{*}{$\begin{array}{l}\text { Fiyalefaj }(\mathrm{A}) \\
\text { Ulee loonii }(\mathrm{O})\end{array}$} & \multirow[t]{3}{*}{$\mathrm{H}$} & $\mathrm{Se}$ & $\mathrm{Hu}$ & Ring worm & $\begin{array}{l}\text { Fresh seed is smashed, mixed with butter and creamed on affected } \\
\text { part. }\end{array}$ & Dermal \\
\hline & & & & $\mathrm{L}$ & $\mathrm{Hu}$ & Ear disease & $\begin{array}{l}\text { Leaf of Clutia abyssinica is pounded, squeezed and then its drop } \\
\text { is added through the ear. }\end{array}$ & Ear \\
\hline & & & & $\mathrm{R}$ & $\mathrm{Hu}$ & Toothache & Fresh root is chewed and kept on teeth for some times. & Oral \\
\hline \multirow[t]{4}{*}{ Coffea Arabica L. } & \multirow[t]{4}{*}{ Rubiaceae } & \multirow[t]{4}{*}{$\begin{array}{l}\operatorname{Buna}(\mathrm{A}) \\
\operatorname{Buna}(\mathrm{O})\end{array}$} & \multirow[t]{4}{*}{ Sh } & \multirow[t]{4}{*}{$\mathrm{Se}$} & $\mathrm{Hu}$ & Diarrhea & $\begin{array}{l}\text { Powder of roasted coffee bean is mixed with butter and eaten or } \\
\text { drunk before breakfast for 3-4 days. }\end{array}$ & Oral \\
\hline & & & & & $\mathrm{Hu}$ & Fire burn & $\begin{array}{l}\text { Seed of Coffea arabica is roasted, pounded, powdered and } \\
\text { applied on affected part. }\end{array}$ & Dermal \\
\hline & & & & & $\mathrm{Hu}$ & Spider poison & $\begin{array}{l}\text { Seed of Coffea arabica is Roasted, powdered, mixed with butter } \\
\text { and painted. }\end{array}$ & Dermal \\
\hline & & & & & $\mathrm{Hu}$ & Eye disease & $\begin{array}{l}\text { Roasted seeds of Coffea Arabica is pounded together with Leaf of } \\
\text { Trigonella foenum-graecum, mixed with butter and rubbed on the } \\
\text { external eye. }\end{array}$ & Eye \\
\hline \multirow[t]{3}{*}{ Cordia africana Lam. } & \multirow[t]{3}{*}{ Boraginaceae } & \multirow{3}{*}{$\begin{array}{l}\text { Wanza(A) } \\
\text { Waddeessa }(O\end{array}$} & \multirow[t]{3}{*}{$\mathrm{T}$} & B & $\mathrm{Hu}$ & $\begin{array}{l}\text { Unstopped } \\
\text { menstruation }\end{array}$ & $\begin{array}{l}\text { Fresh bark is pounded, mixed with water, decanted and drunk with } \\
\text { one coffee cup for three consecutive days }\end{array}$ & Oral \\
\hline & & & & $\mathrm{L}$ & $\mathrm{Hu}$ & Toothache & Fresh leaf is chopped, chewed with salt and the juice is swallowed. & Oral \\
\hline & & & & $\mathrm{Fu}$ & $\mathrm{Hu}$ & $\begin{array}{l}\text { Intestinal } \\
\text { parasites }\end{array}$ & $\begin{array}{l}\text { The Fruit is eaten as food for the case of Intestinal parasites in the } \\
\text { morning before food for } 4-5 \text { consecutive days. }\end{array}$ & Oral \\
\hline \multirow[t]{2}{*}{ Coriandrum sativum L. } & \multirow[t]{2}{*}{ Apiaceae } & \multirow[t]{2}{*}{$\begin{array}{l}\text { Denbelal }(\mathrm{A}) \\
\operatorname{Dinbilaala}(\mathrm{O})\end{array}$} & \multirow[t]{2}{*}{$\mathrm{H}$} & \multirow[t]{2}{*}{$\mathrm{Se}$} & $\mathrm{Hu}$ & Cough & $\begin{array}{l}\text { The seed together with butter and small quantity of water are } \\
\text { boiled and drunk. }\end{array}$ & Oral \\
\hline & & & & & $\mathrm{Hu}$ & Wound & $\begin{array}{l}\text { Leaf of Coriandrum sativum is pounded with leaf of Croton } \\
\text { macrostachyus and Rumex nervosus. Then creamed on wounded } \\
\text { part for 2-3 days. }\end{array}$ & Dermal \\
\hline \multirow[t]{3}{*}{$\begin{array}{l}\text { Croton macrostchyus } \\
\text { Del. }\end{array}$} & \multirow[t]{3}{*}{$\begin{array}{l}\text { Euphorbiacea } \\
\text { e }\end{array}$} & \multirow[t]{3}{*}{$\begin{array}{l}\text { Bisana (A) } \\
\text { Bakkannisa } \\
(\mathrm{O})\end{array}$} & \multirow[t]{3}{*}{$\mathrm{T}$} & Sht & $\mathrm{Hu}$ & Gonorrhea & $\begin{array}{l}\text { Seven, nine or eleven shoot tips is cut, cooked together with Ruta } \\
\text { chalepensis and one spoonful of the solution is drunk per a day for } \\
\text { seven consecutive days. }\end{array}$ & Oral \\
\hline & & & & $\mathrm{B}$ & $\mathrm{Li}$ & Bloating & $\begin{array}{l}\text { The bark of root is ground, mixed with water and given to the } \\
\text { animal. }\end{array}$ & Oral \\
\hline & & & & $\mathrm{L}$ & $\mathrm{Li}$ & Scabies(itches) & $\begin{array}{l}\text { Leaf of Croton macrostachyus with leaf of Brucea antidysenterica } \\
\text { are crushed together and used as skin wash for calf. }\end{array}$ & Dermal \\
\hline \multirow[t]{4}{*}{\begin{tabular}{ll|} 
Cucumis $\quad$ ficifolius \\
A.Rich.
\end{tabular}} & \multirow[t]{4}{*}{ Cucurbitaceae } & \multirow{4}{*}{$\begin{array}{l}\text { Midir } \\
\text { enbuay(A) } \\
\text { Coolotoo( } \\
\text { Hiddii } \\
\text { hooloo(O) }\end{array}$} & \multirow[t]{4}{*}{$\mathrm{Cl}$} & $\mathrm{R}$ & $\mathrm{Hu}$ & Gonorrhea & $\begin{array}{l}\text { Root of Cucumis ficifolius and root of Cyphostemma adenocaule } \\
\text { are crushed and pounded together, mixed with water and decanted, } \\
\text { then mixed with honey and drunk. }\end{array}$ & Oral \\
\hline & & & & $\mathrm{R}$ & $\mathrm{Li}$ & Cattle infection & $\begin{array}{l}\text { Root of Cucumis ficifolius with leaf of Vernonia amygdalina are } \\
\text { pounded together and mixed with cold water. Then given to cattle } \\
\text { by tella material (merti). }\end{array}$ & Oral \\
\hline & & & & $\mathrm{Fu}$ & $\mathrm{Hu}$ & Stomach-ache & $\begin{array}{l}\text { The root of Cucumis ficifolius is chewed and swallowed during the } \\
\text { feeling of ach }\end{array}$ & Oral \\
\hline & & & & $\mathrm{Sa}$ & $\mathrm{Hu}$ & Ear pain & Sap of fruit is added to ear canal. & Ear \\
\hline Cucurbita pepo L. & Cucurbitaceae & $\begin{array}{l}\text { Duba } \\
\text { (A)Dabaaqula } \\
\text { (O) }\end{array}$ & $\mathrm{Cl}$ & $\mathrm{Se}$ & $\mathrm{Hu}$ & Tape worm & Seed of Cucurbita pepo is roasted and eaten before breakfast. & Oral \\
\hline
\end{tabular}




\begin{tabular}{|c|c|c|c|c|c|c|c|c|}
\hline $\begin{array}{l}\text { Cupresses lusitanica } \\
\text { Mill. }\end{array}$ & Cupressaceae & $\begin{array}{l}\text { YeFerenj } \\
\text { tsid(A)Gaattir } \\
\text { aa faranjii(O) }\end{array}$ & $\mathrm{T}$ & $\mathrm{La}$ & $\mathrm{Hu}$ & Ringworm & Latex of Cupresses lusitanica is creamed on affected part of body. & Dermal \\
\hline \multirow{3}{*}{$\begin{array}{l}\text { Cynoglossum } \\
\text { coeruleum } \\
\text { (Hochst.ex.A.rich.) }\end{array}$} & \multirow[t]{3}{*}{ Boraginaceae } & \multirow{3}{*}{$\begin{array}{l}\text { Chigogit(A) } \\
\text { Maxxannee } \\
\text { (O) }\end{array}$} & \multirow[t]{3}{*}{$\mathrm{H}$} & $\mathrm{L}$ & \multirow[t]{3}{*}{$\mathrm{Hu}$} & Headache & Fresh leaf of Cynoglossum coeruleum is massaged and sniffed. & Nasal \\
\hline & & & & $\mathrm{R}$ & & Body swelling & $\begin{array}{l}\text { Fresh root of Cynoglossum coeruleum is chewed and sprayed on } \\
\text { swollen part }\end{array}$ & Dermal \\
\hline & & & & $\mathrm{L}$ & & Scabies(Itches) & Juice of fresh leaves is applied on the skin. & Dermal \\
\hline \multirow{2}{*}{$\begin{array}{l}\text { Cyphostemma } \\
\text { adenocaule (Steud. ex } \\
\text { A. Rich.) Des. ex Wild } \\
\text { \& Drum. }\end{array}$} & \multirow[t]{2}{*}{ Vitaceae } & \multirow{2}{*}{$\begin{array}{l}\text { Aserkush(A) } \\
\text { Hidda } \\
\text { Bofaa }(\mathrm{O})\end{array}$} & \multirow[t]{2}{*}{$\mathrm{Cl}$} & $\mathrm{Tu}$ & $\mathrm{Hu}$ & starvation & Tuber is cooked and eaten during famine & Oral \\
\hline & & & & $\mathrm{Ag}$ & $\mathrm{Li}$ & $\begin{array}{l}\text { Infection on } \\
\text { Neck(livestock) }\end{array}$ & Tied on the livestock's neck. & Neck \\
\hline \multirow[t]{4}{*}{ Datura stramonium L. } & \multirow[t]{4}{*}{ Solanaceae } & \multirow[t]{4}{*}{$\begin{array}{l}\text { Astanagir(A) } \\
\text { Manjii (O) }\end{array}$} & \multirow[t]{4}{*}{$\mathrm{H}$} & $\mathrm{L}$ & $\mathrm{Hu}$ & Dandruff & $\begin{array}{l}\text { Leaf is crushed with leaf of Myrtus communis \& the powder is } \\
\text { rubbed over the head after having cut the hair. }\end{array}$ & Dermal \\
\hline & & & & $\mathrm{R}$ & $\mathrm{Hu}$ & Headache & $\begin{array}{l}\text { Roots of Datura stramonium is pounded with leaf of Ocimum } \\
\text { gratissimum and sniffed Nasally. }\end{array}$ & Nasal \\
\hline & & & & $\mathrm{Fu}$ & $\mathrm{Hu}$ & Scabies(itches) & $\begin{array}{l}\text { About 2-3 spoons of Powdered fruit of Datura stramonium is } \\
\text { mixed with butter and creamed. }\end{array}$ & Dermal \\
\hline & & & & $\mathrm{L}$ & $\mathrm{Hu}$ & Wound & $\begin{array}{l}\text { Fresh leaf of Datura stramonium is squeezed and creamed the } \\
\text { affeacted (wounded) part of the body. }\end{array}$ & Dermal \\
\hline \multirow[t]{2}{*}{$\begin{array}{l}\text { Discopodium } \\
\text { penninervum Hochst. }\end{array}$} & \multirow[t]{2}{*}{ Solanaceae } & \multirow[t]{2}{*}{ Almit(a) } & \multirow[t]{2}{*}{ Sh } & \multirow[t]{2}{*}{$\mathrm{L}$} & $\mathrm{Li}$ & Leech & $\begin{array}{l}\text { The leaf of Dispcopodium penninervum is pounded, mixed with } \\
\text { little water and the decanted is given to cattle. }\end{array}$ & Oral \\
\hline & & & & & $\mathrm{Li}$ & Bloating & $\begin{array}{l}\text { The fresh leaf of Dispcopodium penninervum is pounded, } \\
\text { squeezed, mixed with water, decanted and given to cattle. }\end{array}$ & Oral \\
\hline \multirow{4}{*}{$\begin{array}{l}\text { Dodonaea angustifolia } \\
\text { L. }\end{array}$} & \multirow[t]{4}{*}{ Sapindaceae } & \multirow{4}{*}{$\begin{array}{l}\text { Kitkita(A) } \\
\text { Ittacha(O) }\end{array}$} & \multirow[t]{4}{*}{$\mathrm{Sh}$} & \multirow[t]{4}{*}{$\mathrm{L}$} & $\mathrm{Hu}$ & Diarrhea & Fresh leaves are pounded, mixed with water, decanted and drunk. & Oral \\
\hline & & & & & $\mathrm{Hu}$ & Skin rash & Fresh leaves are crushed, mixed with water and painted the skin. & Dermal \\
\hline & & & & & $\mathrm{Li}$ & Wound & $\begin{array}{l}\text { Dried leaves of Dodonaea angustifolia are powdered and sprayed } \\
\text { on the wound of pack (domesticated) animals. }\end{array}$ & Dermal \\
\hline & & & & & & Ecto-parasities & $\begin{array}{l}\text { Fresh leafs are crushed and pounded with water, then leaf extract } \\
\text { is given Orally and pounded leaves are painted on the cattle body. }\end{array}$ & Dermal \\
\hline \multirow[t]{2}{*}{$\begin{array}{l}\text { Dombeya torrida (J. F. } \\
\text { Gmel.) P. Bamps }\end{array}$} & \multirow[t]{2}{*}{ Sterculiaceae } & \multirow[t]{2}{*}{$\begin{array}{l}\text { Wulkifa (A) } \\
\text { Daannisa(O) }\end{array}$} & \multirow[t]{2}{*}{$\mathrm{T}$} & \multirow[t]{2}{*}{$\mathrm{L}$} & \multirow[t]{2}{*}{$\mathrm{Hu}$} & Fire burn & $\begin{array}{l}\text { Fresh leaf of Dombeya torrida is squeezed and creamed on } \\
\text { affected part. }\end{array}$ & Dermal \\
\hline & & & & & & Abdominal pain & Dried leaf powder is mixed with honey and given Orally. & Oral \\
\hline $\begin{array}{l}\text { Dovyalis abyssinica } \\
\text { (A.Rich.)Warb. }\end{array}$ & $\begin{array}{l}\text { Flacourtiacea } \\
\text { e }\end{array}$ & $\begin{array}{l}\operatorname{Koshim}(\mathrm{A}) \mathrm{Ko} \\
\text { shommii }(\mathrm{O})\end{array}$ & Sh & $\mathrm{Fu}$ & $\mathrm{Hu}$ & $\begin{array}{l}\text { Intestinal } \\
\text { Parasites }\end{array}$ & $\begin{array}{l}\text { Its fruit is eaten as food for the case of intestinal parasite before } \\
\text { breakfast every morning }\end{array}$ & Oral \\
\hline \multirow[t]{4}{*}{$\begin{array}{l}\text { Echinops } \\
\text { keberichoMesfin }\end{array}$} & \multirow[t]{4}{*}{ Asteraceae } & \multirow{4}{*}{$\begin{array}{l}\text { Kerebicho }(\mathrm{A}) \\
\text { Qarabichoo }(\mathrm{O}\end{array}$} & \multirow[t]{4}{*}{$\mathrm{H}$} & $\mathrm{R}$ & $\mathrm{Hu}$ & Evil eye & $\begin{array}{l}\text { Root concoction together with Leaf of Artemisia abyssinica is } \\
\text { added to a burning fire and smoked to the patient. }\end{array}$ & Nasal \\
\hline & & & & $\mathrm{R}$ & $\mathrm{Hu}$ & Rabies & $\begin{array}{l}\text { Root concoction together with root of Ricinus communis is boiled } \\
\text { and decoction is drunk. }\end{array}$ & Oral \\
\hline & & & & $\mathrm{R}$ & $\mathrm{Hu}$ & Evil Spirit & Root is Crushed, heated on fire and its smoke is inhaled. & Nasal \\
\hline & & & & $\mathrm{R}$ & $\mathrm{Hu}$ & Tetanus & $\begin{array}{l}\text { Root of E. kebericho with bark of Croton macrostachys is } \\
\text { pounded, powdered together, mixed with honey and then one cup } \\
\text { of the mixture is taken for } 3 \text { days. }\end{array}$ & Oral \\
\hline
\end{tabular}




\begin{tabular}{|c|c|c|c|c|c|c|c|c|}
\hline \multirow[t]{2}{*}{$\begin{array}{l}\text { Embelia } \\
\text { Vatke }\end{array}$} & \multirow[t]{2}{*}{ Myrsinaceae } & \multirow[t]{2}{*}{$\begin{array}{l}\text { Enkoko (A) } \\
\text { Haanquu }(\mathrm{O})\end{array}$} & \multirow[t]{2}{*}{$\mathrm{Sh}$} & $\mathrm{Se}$ & $\mathrm{Hu}$ & Tape worm & $\begin{array}{l}\text { Seed of Embelia schimperi is dried and powdered, mixed with } \\
\text { water, two glasses are taken in the morning before food and stay } \\
\text { for 6-7 hours. }\end{array}$ & Oral \\
\hline & & & & $\mathrm{Fu}$ & $\mathrm{Hu}$ & Epilepsy & $\begin{array}{l}\text { Fruit of Embelia schimperi with seed of Guizotia abyssinica is } \\
\text { crushed, powdered, mixed with local alcohol "tej"and drunk }\end{array}$ & Oral \\
\hline \multirow[t]{2}{*}{ Erica arborea $\mathrm{L}$. } & \multirow[t]{2}{*}{ Ericaceae } & \multirow[t]{2}{*}{$\begin{array}{l}\operatorname{Asta}(\mathrm{A}) \\
\operatorname{Maxaxee}(\mathrm{O})\end{array}$} & \multirow[t]{2}{*}{$\mathrm{T}$} & Sht & $\mathrm{Hu}$ & Giardiasis & $\begin{array}{l}\text { Shoot is boiled and the decoction is drunk for 3-4 days } \\
\text { consecutively. }\end{array}$ & Oral \\
\hline & & & & $\mathrm{L}$ & $\mathrm{Hu}$ & Wound & $\begin{array}{l}\text { The powder of dried leaves is mixed with butter \& rubbed on the } \\
\text { affected part. }\end{array}$ & Dermal \\
\hline \multirow[t]{4}{*}{$\begin{array}{l}\text { Eucalyptus globulus } \\
\text { Labill. }\end{array}$} & \multirow[t]{4}{*}{ Myrtaceae } & \multirow{4}{*}{$\begin{array}{l}\text { Nech } \\
\text { bahirzaf(A) } \\
\text { Bargamoo } \\
\text { adii(O) }\end{array}$} & \multirow[t]{4}{*}{$\mathrm{T}$} & $\mathrm{L}$ & $\mathrm{Hu}$ & Influenza & $\begin{array}{l}\text { The Leaf of Eucalyptus globulus is chopped and Boiled with water } \\
\text { and inhale the vapor repeatedly. }\end{array}$ & Oral/Nasal \\
\hline & & & & St & $\mathrm{Hu}$ & Fibril illness & $\begin{array}{l}\text { The young leaves and immature stem tip are boiled in water and } \\
\text { the steam is inhaled by the patient during the sleep time until } \\
\text { recovery. }\end{array}$ & Nasal \\
\hline & & & & $\mathrm{L}$ & $\mathrm{Hu}$ & Malaria & Dried leaf is put on fire and smoked & Nasal \\
\hline & & & & $\mathrm{L}$ & $\mathrm{Hu}$ & Cough & Leaf is boiled with sugar and one tea cup of syrup is drunk. & Oral \\
\hline \multirow[t]{3}{*}{$\begin{array}{l}\text { Euphorbia abyssinica. } \\
\text { Gmel }\end{array}$} & \multirow[t]{3}{*}{$\begin{array}{l}\text { Euphorbiacea } \\
\mathrm{e}\end{array}$} & \multirow[t]{3}{*}{$\begin{array}{l}\text { Kulkual (A) } \\
\text { Adaammii (A) }\end{array}$} & \multirow[t]{3}{*}{$\mathrm{T}$} & Fw & $\mathrm{Hu}$ & Wound & $\begin{array}{l}\text { Fresh flower of Euphorbia abyssinica is squeezed and creamed } \\
\text { on affected part }\end{array}$ & Dermal \\
\hline & & & & $\mathrm{B}$ & $\mathrm{Hu}$ & Ascariasis & $\begin{array}{l}\text { Fine powder of pounded bark of Euphorbiaabyssinica and Croton } \\
\text { macrostachyus is mixed with water, decanted and taken at meal } \\
\text { time. }\end{array}$ & Oral \\
\hline & & & & $\mathrm{La}$ & $\mathrm{Hu}$ & Gonerrhea & $\begin{array}{l}\text { Very small amount of the milky latex is mixed with red teff flour, } \\
\text { baked and eaten for three consecutive days. }\end{array}$ & Oral \\
\hline \multirow[t]{3}{*}{ Guizotia abyssinica L. } & \multirow[t]{3}{*}{ Asteraceae } & \multirow[t]{3}{*}{$\begin{array}{l}\operatorname{Nug}(A) \\
\text { Nuugii(O) }\end{array}$} & \multirow[t]{3}{*}{$\mathrm{H}$} & $\mathrm{Se}$ & $\mathrm{Hu}$ & Kidney Problem & $\begin{array}{l}\text { Seed of Guizotia abyssinica is roasted, pounded and mixed with } \\
\text { powdered leaves of Thymus schimperi and boiled. Then one coffee } \\
\text { cup is drunk for 3-5 days. }\end{array}$ & Oral \\
\hline & & & & $\mathrm{Se}$ & $\mathrm{Hu}$ & Swelling & $\begin{array}{l}\text { Seed is roasted, pounded and powdered, then boiled with salt and } \\
\text { the syrup is drunk. }\end{array}$ & Oral \\
\hline & & & & $\mathrm{Se}$ & $\mathrm{Li}$ & Leech & $\begin{array}{l}\text { More than one litter powdered seed mixed with water is given to } \\
\text { cattles for three days continuously. }\end{array}$ & Oral \\
\hline \multirow[t]{4}{*}{$\begin{array}{l}\text { Hagenia abyssinica } \\
\text { (Bruce) J. F. Gmel. }\end{array}$} & \multirow[t]{4}{*}{ Rosaceae } & \multirow[t]{4}{*}{$\begin{array}{l}\text { Koso }(\mathrm{A}) \\
\text { Heexoo(O) }\end{array}$} & \multirow[t]{4}{*}{$\mathrm{T}$} & $\mathrm{Fu}$ & $\mathrm{Hu}$ & stomach-ache & $\begin{array}{l}\text { Fresh fruit is crushed, squeezed and the juice is mixed with tella } \\
\text { and drunk. }\end{array}$ & Oral \\
\hline & & & & $\mathrm{Se}$ & $\mathrm{Hu}$ & $\begin{array}{l}\text { Venereal disease } \\
\text { (abalazar) }\end{array}$ & Dried Seed is powdered, mixed with tela and drunk. & Oral \\
\hline & & & & $\mathrm{Se}$ & $\mathrm{Hu}$ & Eczema & $\begin{array}{l}\text { Calf horn and roasted Hagenia abyssinica seed are pounded } \\
\text { together, mixed with butter and creamed on affected body part. }\end{array}$ & Dermal \\
\hline & & & & $\mathrm{Se}$ & $\mathrm{Hu}$ & Tape worm & $\begin{array}{l}\text { The seed of Hagenia abyssinica is crushed, powdered, mixed with } \\
\text { milk, boiled and drunk for five days before breakfast. }\end{array}$ & Oral \\
\hline \multirow{3}{*}{$\begin{array}{l}\text { Hypericum revolutum } \\
\text { Vahl }\end{array}$} & \multirow[t]{3}{*}{ Hypericaceae } & \multirow{3}{*}{$\begin{array}{l}\text { Amja (A) } \\
\text { Muka } \\
\text { Foonii(O) }\end{array}$} & \multirow[t]{3}{*}{ Sh } & $\mathrm{L}$ & $\mathrm{Hu}$ & Erythroblasts & Leaf is boiled with water and the decoction is drunk. & Oral \\
\hline & & & & Sht & $\mathrm{Hu}$ & Dandruff & $\begin{array}{l}\text { Shoot is crushed, squeezed and the sap is creamed after having cut } \\
\text { hair. }\end{array}$ & Dermal \\
\hline & & & & $\begin{array}{l}\mathrm{L} / \\
\mathrm{R}\end{array}$ & $\mathrm{Li}$ & Rabies & $\begin{array}{l}\text { The root and leaf of Hypericum revolutum together with roots of } \\
\text { Rumex nervosus, Phytolacca dodecandra, Brucea }\end{array}$ & Oral \\
\hline
\end{tabular}




\begin{tabular}{|c|c|c|c|c|c|c|c|c|}
\hline & & & & & & & $\begin{array}{l}\text { antidysenterica, leaf and bark of Croton macrostachyus are } \\
\text { pounded together, mixed with water and given to cattle. }\end{array}$ & \\
\hline $\begin{array}{l}\text { Jasminum abyssinicum } \\
\text { L. }\end{array}$ & Oleaceae & $\begin{array}{l}\text { Tembelel } \\
\text { Biluu(O) }\end{array}$ & $\mathrm{Cl}$ & $\mathrm{L}$ & $\mathrm{Hu}$ & Eye disease & $\begin{array}{l}\text { The leaves of Jusminium abysinicum and seven pieces of } \\
\text { immature stems of Olea europaea are ground and powdered } \\
\text { together, mixed with water and drop of mixture is applied on } \\
\text { infected part for } 3 \text { days. }\end{array}$ & Eye \\
\hline \multirow{3}{*}{$\begin{array}{l}\text { Juniperus procera } \\
\text { Endl. }\end{array}$} & \multirow[t]{3}{*}{ Cupressaceae } & \multirow{3}{*}{$\begin{array}{l}\text { Ye abesha } \\
\text { tsid(A) } \\
\text { Gaattiraa }(\mathrm{O})\end{array}$} & \multirow[t]{3}{*}{$\mathrm{T}$} & $\mathrm{B}$ & $\mathrm{Hu}$ & Tonsillitis & Fresh stem bark is chewed and the juice is swallowed. & Oral \\
\hline & & & & B & $\mathrm{Hu}$ & Malaria & Dried bark is boiled with water and the decoction is drunk. & Oral \\
\hline & & & & $\mathrm{L}$ & $\mathrm{Hu}$ & Pneumonia & $\begin{array}{l}\text { Fresh leaf is Crushed and steeped in cold water and the infusion is } \\
\text { drunk. }\end{array}$ & Oral \\
\hline \multirow{4}{*}{$\begin{array}{l}\text { Justicia schimperiana } \\
\text { (Hochst. exNees) T. } \\
\text { Anders }\end{array}$} & \multirow[t]{4}{*}{ Acanthaceae } & \multirow{4}{*}{$\begin{array}{l}\text { Simiza(sensel } \\
\text { (A) } \\
\text { DHummuuga } \\
a(O)\end{array}$} & \multirow[t]{4}{*}{ Sh } & $\mathrm{L}$ & $\mathrm{Li}$ & $\begin{array}{l}\text { Hen disease } \\
\text { (Cocoidiosi) }\end{array}$ & $\begin{array}{l}\text { The leaf (shoot) is crushed, mixed with water and decanted; } \\
\text { 'Enjera' (bread) is soaked with the solution and given to the hen. }\end{array}$ & Oral \\
\hline & & & & $\mathrm{L} / \mathrm{R}$ & $\mathrm{Li}$ & Blackleg & $\begin{array}{l}\text { Leaf and root of Justica schimperiana is pounded with dried fruit } \\
\text { of Ricinus communis and the solution is given to cattle. }\end{array}$ & Oral \\
\hline & & & & $\mathrm{L}$ & $\mathrm{Hu}$ & Leg swelling & $\begin{array}{l}\text { Fresh Leaf is heated on fire; salt is added to it and tied on the } \\
\text { swollen part. }\end{array}$ & Dermal \\
\hline & & & & $\mathrm{L}$ & $\mathrm{Li}$ & Lice & $\begin{array}{l}\text { Leaf of Justicia schimperiana with leaf of Calpurina aurea are } \\
\text { used to wash the body of cattle to remove the lice. }\end{array}$ & Dermal \\
\hline \multirow[t]{3}{*}{$\begin{array}{l}\text { Kalanchoe petitiana A. } \\
\text { Rich. }\end{array}$} & \multirow[t]{3}{*}{$\begin{array}{l}\text { Euphorbiacea } \\
\text { e }\end{array}$} & \multirow[t]{3}{*}{$\begin{array}{l}\text { Endawula (A) } \\
\text { Bosoqqee }(\mathrm{O})\end{array}$} & \multirow[t]{3}{*}{$\mathrm{H}$} & $\mathrm{R}$ & $\mathrm{Hu}$ & Bone fracture & $\begin{array}{l}\text { Fresh leaf is squeezed; the juice is mixed with butter and applied } \\
\text { topically on fractured part. }\end{array}$ & Dermal \\
\hline & & & & $\mathrm{L}$ & $\mathrm{Hu}$ & Wound & $\begin{array}{l}\text { Fresh leaf is heated with fire, squeezed and the juice is dropped } \\
\text { on wounded part }\end{array}$ & Dermal \\
\hline & & & & $\mathrm{R}$ & $\mathrm{Hu}$ & Ear disease & $\begin{array}{l}\text { Fresh root of Kalanchoe petitiana is squeezed and few drops are } \\
\text { added through ear canal. }\end{array}$ & Ear \\
\hline \multirow[t]{2}{*}{$\begin{array}{l}\text { Kosteletzkya } \\
\text { begonifolia } \text { Ulbr. }\end{array}$} & \multirow[t]{2}{*}{ Malvaceae } & \multirow[t]{2}{*}{$\begin{array}{l}\text { Yemegerem } \\
\text { (A) }\end{array}$} & \multirow[t]{2}{*}{$\overline{\mathrm{H}}$} & $\mathrm{R}$ & $\mathrm{Li}$ & For anthrax & $\begin{array}{l}\text { Fresh leaf of Kosteletzka begonifolia is pounded squeezed mixed } \\
\text { with"tella" and drunk. }\end{array}$ & \multirow[t]{2}{*}{ Oral } \\
\hline & & & & $\mathrm{R}$ & $\mathrm{Hu}$ & $\begin{array}{ll}\text { For } & \text { body } \\
\text { swelling }\end{array}$ & $\begin{array}{l}\text { Fresh leaf of Kosteletzka begonifolia is pounded squeezed mixed } \\
\text { with"tella" and drunk. }\end{array}$ & \\
\hline \multirow[t]{4}{*}{ Linum usitatissimum L. } & \multirow[t]{4}{*}{ Lineaceae } & \multirow[t]{4}{*}{$\begin{array}{l}\text { Telba(A) } \\
\text { Talbaa }(\mathrm{O})\end{array}$} & \multirow[t]{4}{*}{$\mathrm{H}$} & $\mathrm{Se}$ & $\mathrm{Hu}$ & Wound & $\begin{array}{l}\text { Seed of Linum usitatissimum is pounded, mixed with honey and } \\
\text { creamed on wounded part }\end{array}$ & Dermal \\
\hline & & & & $\mathrm{Se}$ & $\mathrm{Li}$ & $\begin{array}{l}\text { Retained } \\
\text { placenta }\end{array}$ & $\begin{array}{l}\text { Seed of Linum usitatissimum is powdered and half of a glass of the } \\
\text { powder is dissolved in water and given to cattle. }\end{array}$ & Oral \\
\hline & & & & $\mathrm{Se}$ & $\mathrm{Hu}$ & Amoeba & The pounded seed is mixed with water and drunk before breakfast. & Oral \\
\hline & & & & $\mathrm{Se}$ & $\mathrm{Hu}$ & Gastritis & $\begin{array}{l}\text { The seed of Linum usitatissimum is pounded, mixed water and } \\
\text { sugar and then drunk during feeling the pain. }\end{array}$ & Oral \\
\hline \multirow[t]{2}{*}{$\begin{array}{l}\text { Lobelia } \\
\text { rhynchopetalum } \\
\text { Hemsl. }\end{array}$} & \multirow[t]{2}{*}{ Lobeliaceae } & \multirow[t]{2}{*}{ Jibira(A) } & \multirow[t]{2}{*}{ Sh } & $\begin{array}{l}\mathrm{B} \text { and } \\
\mathrm{R}\end{array}$ & $\mathrm{Hu}$ & Evil eye & $\begin{array}{l}\text { The bark and root of Lobelia rhynchopetalum is crushed, mixed } \\
\text { with little water and sniffed at the sickness time or the dried root } \\
\text { is tied with piece of cloth around the neck or put it in the pocket. }\end{array}$ & $\begin{array}{l}\text { Nasal } \\
\text { and Dermal }\end{array}$ \\
\hline & & & & $\mathrm{R}$ & $\mathrm{Hu}$ & Scabies(itches) & $\begin{array}{l}\text { Root of Lobelia rhynchopetalum is dried, powdered, mixed with } \\
\text { butter, rub the body for some days and finally taking a shower at } \\
\text { the end of the day. }\end{array}$ & Dermal \\
\hline Lepidium sativum $\mathrm{L}$. & Brassicaceae & $\begin{array}{l}\text { Feto(A) } \\
\text { Feecoo(O) }\end{array}$ & $\mathrm{H}$ & $\mathrm{Se}$ & $\mathrm{Hu}$ & Bloating & $\begin{array}{l}\text { Seed of Lepidium sativum and bulb of Allium sativum are pounded } \\
\text { together, mixed with water and given to cattle. }\end{array}$ & Oral \\
\hline
\end{tabular}




\begin{tabular}{|c|c|c|c|c|c|c|c|c|}
\hline & & & & $\mathrm{Se}$ & $\mathrm{Hu}$ & Dysentery & $\begin{array}{l}\text { The seed of Lepidium sativum is ground, mixed with milk, then } \\
\text { filtrate and the solution is drunk. }\end{array}$ & Oral \\
\hline & & & & $\mathrm{Se}$ & $\mathrm{Hu}$ & Malaria & $\begin{array}{l}\text { Seed of Lepidium sativum, bulb of Allium sativum and rhizome of } \\
\text { Zingiber officinale are pounded together and given to Human with } \\
\text { honey. }\end{array}$ & Oral \\
\hline & & & & $\mathrm{Se}$ & $\mathrm{Hu}$ & Tonsilitis & $\begin{array}{l}\text { Seed of Lepidium sativum and bulb of Allium sativum are pounded } \\
\text { together and given to Human with honey. }\end{array}$ & Oral \\
\hline & & & & $\mathrm{Se}$ & $\mathrm{Hu}$ & Fibril illness & $\begin{array}{l}\text { Dried seeds are powdered and added in to fire and smoked to the } \\
\text { patient. }\end{array}$ & Nasal /Oral \\
\hline & & & & $\mathrm{St}$ & $\mathrm{Hu}$ & Hemorrhoids & Stem is heated on fire and used to burn the affected part & Dermal \\
\hline $\begin{array}{ll}\text { Maesa } \quad \text { lanceolata } \\
\text { Forssk. }\end{array}$ & Myrsinaceae & $\begin{array}{l}\text { Shwaria( } \\
\text { kelawa ) (A) }\end{array}$ & $\mathrm{Sh}$ & $\begin{array}{l}\text { L and } \\
\text { Se }\end{array}$ & $\mathrm{Li}$ & For leeches & $\begin{array}{l}\text { Dried leaf and fruit of Maesa lanceolata are crushed, pounded } \\
\text { and the powder is added to water to kill leeches }\end{array}$ & Oral \\
\hline & & & & $\mathrm{R}$ & $\mathrm{Li}$ & $\begin{array}{l}\text { Retention of } \\
\text { placenta }\end{array}$ & $\begin{array}{l}\text { Root of Maesa lanceolata is boiled with seed of Linum } \\
\text { usitatissimum and given to cattle. }\end{array}$ & Oral \\
\hline & & & & $\mathrm{L}$ & $\mathrm{Hu}$ & Eczema(chife) & $\begin{array}{l}\text { Dried leaf powder together with the powder of leaf of Croton } \\
\text { macrosrachyus are pasted with butter and applied for seven days } \\
\text { consecutively. }\end{array}$ & Dermal \\
\hline azedarach & Meliaceae & $\operatorname{Nim}(\mathrm{A})$ & $\mathrm{T}$ & $\mathrm{L}$ & $\mathrm{Hu}$ & Malaria & Chewing and swallowing the juice of fresh leaf. & Oral \\
\hline Forssk. & & $\operatorname{Niimii}(\mathrm{O})$ & & $\mathrm{B}$ & $\mathrm{Li}$ & Anthrax & $\begin{array}{l}\text { The fine powder of dried bark is added to a glass of water and } \\
\text { applied through the mouth. }\end{array}$ & Oral \\
\hline & & & & Sht & $\mathrm{Hu}$ & Tooth ache & Young shoot tip is chewed and kept on the teeth. & Oral \\
\hline Myrtus communis L. & Myrtaceae & $\begin{array}{l}\text { Ades(A) } \\
\text { Adasii(O) }\end{array}$ & Sh & $\mathrm{L}$ & Both & $\begin{array}{l}\text { Intestinal } \\
\text { parasites }\end{array}$ & $\begin{array}{l}\text { Dried leaf of Myrtus communis is pounded, added to tella and } \\
\text { drunk to expel intestinal parasites. }\end{array}$ & Oral \\
\hline & & & & $\mathrm{L}$ & $\mathrm{Hu}$ & Dandruff & $\begin{array}{l}\text { The leaf of Myrtus communis is powdered, mixed with butter and } \\
\text { creamed on head after is cut. }\end{array}$ & Dermal \\
\hline & & & & $\mathrm{L}$ & $\mathrm{Hu}$ & Scabies(itches) & Dried powder is mixed with butter \& applied on the affected part & Dermal \\
\hline Nicotiana tabacum $\mathrm{L}$. & Solanaceae. & $\begin{array}{l}\text { Timbaho(A) } \\
\text { Tamboo(O) }\end{array}$ & $\mathrm{H}$ & $\mathrm{L}$ & $\mathrm{Hu}$ & Snake bite & $\begin{array}{l}\text { Leaf of Nicotiana tabacum is crushed and squeezed, mixed with } \\
\text { water and the Juice is drunk to expel the poison by vomiting. }\end{array}$ & Oral \\
\hline & & & & $\mathrm{L}$ & $\mathrm{Li}$ & Bloating & $\begin{array}{l}\text { Leaf and root of Nicotiana tabacum is dried, powdered, mixed } \\
\text { with salt, water and made as bread. Slice is given to cattle before } \\
\text { they drink water for three days. }\end{array}$ & Oral \\
\hline & & & & $\mathrm{St} / \mathrm{L}$ & $\mathrm{Li}$ & Leech & $\begin{array}{l}\text { The young stems and or leaf is ground, add salt, and then one glass } \\
\text { of the mixture is given every morning for three days orally or } \\
\text { through the nose. }\end{array}$ & Oral \\
\hline & & & & $\mathrm{L}$ & $\mathrm{Li}$ & Internal parasites & $\begin{array}{l}\text { Leaf of Nicotiana tabacum is pounded with root of Carissa } \\
\text { spinarum and mixed with water. One merit solution is given to } \\
\text { calf. }\end{array}$ & Oral \\
\hline Nigella sativa $\mathrm{L}$. & Ranunculacea & Tikur & $\mathrm{H}$ & $\mathrm{Se}$ & $\mathrm{Hu}$ & Depression & Seed is added to tea and drunk to stimulate mental. & Oral \\
\hline & & $\begin{array}{l}\text { azmud(A) } \\
\text { Abasuuda }\end{array}$ & & $\mathrm{Se}$ & $\mathrm{Hu}$ & Tonsillitis & $\begin{array}{l}\text { Seed of Nigella sativa is pounded, powdered and added to coffee. } \\
\text { Then drunk for 3-4 consecutive days. }\end{array}$ & Oral \\
\hline & & gurraacha $(\mathrm{O})$ & & $\mathrm{Se}$ & $\mathrm{Hu}$ & Stomach-ache & $\begin{array}{l}\text { Seed is crushed and pounded with Ruta chalepensis, Lepidium } \\
\text { sativum and Allium sativum then mixed with honey and a spoonful } \\
\text { of the mixture is taken before breakfast. }\end{array}$ & Oral \\
\hline
\end{tabular}




\begin{tabular}{|c|c|c|c|c|c|c|c|c|}
\hline \multirow[t]{3}{*}{ Ocimum basilicum $\mathrm{L}$. } & \multirow[t]{3}{*}{ Lamiaceae } & \multirow{3}{*}{$\begin{array}{l}\text { Zikakibe(A) } \\
\text { Gosobila(O) }\end{array}$} & \multirow[t]{3}{*}{$\mathrm{H}$} & $\mathrm{L}$ & $\mathrm{Hu}$ & Headache & Leaf of Ocimum basilicum is crushed and sniffed. & Nasal \\
\hline & & & & $\mathrm{L}$ & $\mathrm{Hu}$ & Malaria & $\begin{array}{l}\text { Leaf of Ocimum basilicum and bulb of Allium sativum are } \\
\text { pounded together and eaten with honey in the morning. }\end{array}$ & Oral \\
\hline & & & & $\mathrm{L}$ & $\mathrm{Li}$ & Bloating & $\begin{array}{l}\text { Its fresh leaves with the bulb of Allium sativum and salt are ground } \\
\text { together and then one litter of the solution is given to cattle. }\end{array}$ & Oral \\
\hline \multirow[t]{2}{*}{$\begin{array}{l}\text { Ocimum lamiifolium } \\
\text { Hochst. ex Benth. }\end{array}$} & \multirow[t]{2}{*}{ Lamiaceae } & \multirow[t]{2}{*}{$\begin{array}{l}\text { Damakese }(\mathrm{A}) \\
\operatorname{Damakasee}(\mathrm{O}\end{array}$} & \multirow[t]{2}{*}{ Sh } & $\mathrm{L}$ & $\mathrm{Hu}$ & Febrile illness & $\begin{array}{l}\text { Fresh leaf of Ocimum lamiifolium together with leaf of Eucalyptus } \\
\text { globulus, is pounded, mixed with water and drunk or the patient } \\
\text { can inhale the vapor of the boiled mixture. }\end{array}$ & Oral \\
\hline & & & & $\mathrm{L}$ & $\mathrm{Hu}$ & Headache & Leaf of Ocimum lamiifolium is massaged and sniffed. & Oral \\
\hline \multirow{4}{*}{$\begin{array}{lr}\text { Olea } & \text { europaea } L . \\
\text { subsp. } & \text { cuspidata } \\
\text { (Wall. ex } & \text { G. Don) Cif. }\end{array}$} & \multirow[t]{4}{*}{ Oleaceae } & \multirow[t]{4}{*}{$\begin{array}{l}\text { Weyra(A) } \\
\operatorname{Ejersa}(\mathrm{O})\end{array}$} & \multirow[t]{4}{*}{$\mathrm{T}$} & $\mathrm{L}$ & Both & Eye disease & $\begin{array}{l}\text { Leaf is Crushed and squeezed. Then the sap is dropped by piece } \\
\text { of clean cloth on eye. }\end{array}$ & Eye \\
\hline & & & & St & $\mathrm{Hu}$ & Wound & $\begin{array}{l}\text { Fresh stem is heated on fire and the oily liquid produced from the } \\
\text { stem is applied on the wound. }\end{array}$ & Dermal \\
\hline & & & & St & $\mathrm{Hu}$ & Gastiritis & $\begin{array}{l}\text { Oily liquid produced from the stem is drunk after meal for three } \\
\text { consecutive days. }\end{array}$ & Oral \\
\hline & & & & $\mathrm{B}$ & $\mathrm{Hu}$ & Haemorrhoid & The bark is heated on fire and held on the pain area. & Dermal \\
\hline \multirow[t]{2}{*}{$\begin{array}{l}\text { Opuntia ficus-indica } \\
\text { (L.) Miller }\end{array}$} & \multirow[t]{2}{*}{ Cactaceae } & \multirow{2}{*}{$\begin{array}{l}\text { Balas } \\
\text { (Ashewa } \\
\text { kulkual(A) } \\
\text { Adaammmii( } \\
\text { O) }\end{array}$} & \multirow[t]{2}{*}{ Sh } & $\mathrm{L}$ & $\mathrm{Hu}$ & Ear disease & $\begin{array}{l}\text { Leaf of Opuntia ficus-indica is squeezed and the sap is dropped } \\
\text { through ear canal safely. }\end{array}$ & Ear \\
\hline & & & & $\mathrm{Fu}$ & $\mathrm{Hu}$ & Stomach-ache & Ripened fruit is eaten & Oral \\
\hline \multirow[t]{3}{*}{$\begin{array}{l}\text { Otostegia integrifolia } \\
\text { Benth. }\end{array}$} & \multirow[t]{3}{*}{ Lamiaceae } & \multirow[t]{3}{*}{$\begin{array}{l}\text { Tunjit(A) } \\
\text { Xunjiitii }(\mathrm{O}\end{array}$} & \multirow[t]{3}{*}{ Sh } & \multirow[t]{3}{*}{$\mathrm{L}$} & $\mathrm{Hu}$ & Stomach-ache & $\begin{array}{l}\text { Leaf of Otostegia integrifolia and leaf of Solanum adoense are } \\
\text { crushed, squeezed together and the juice or sap is drunk. }\end{array}$ & Oral \\
\hline & & & & & $\mathrm{Hu}$ & Fibril illness & Dried leaf is added to fire and fumigated & Oral and Nasal \\
\hline & & & & & $\mathrm{Hu}$ & Tonsillitis & $\begin{array}{l}\text { Fresh leaf of Otostegia integrifolia is squeezed and half of coffee } \\
\text { cup is drunk }\end{array}$ & Oral \\
\hline \multirow[t]{2}{*}{$\begin{array}{l}\text { Osyris quadripartita } \\
\text { Decn }\end{array}$} & \multirow[t]{2}{*}{ Santalaceae } & \multirow[t]{2}{*}{$\begin{array}{l}\text { Keret }(\mathrm{A}) \\
\text { Waatoo }(\mathrm{O})\end{array}$} & \multirow[t]{2}{*}{ Sh } & St & $\mathrm{Hu}$ & Stomach-ache & Fresh stem bark of is chewed \& the solution is swallowed. & Oral \\
\hline & & & & $\mathrm{L}$ & $\mathrm{Hu}$ & Wound & $\begin{array}{l}\text { Dried or fresh leaf of is crushed, powdered and then applied on the } \\
\text { wound part }\end{array}$ & Dermal \\
\hline \multirow[t]{4}{*}{$\begin{array}{l}\text { Phytolacca } \\
\text { dodecandra L' Herit. }\end{array}$} & \multirow[t]{4}{*}{$\begin{array}{l}\text { Phytolaccacea } \\
\text { e }\end{array}$} & \multirow[t]{4}{*}{$\begin{array}{l}\text { Endod(A) } \\
\text { Handoodee }(\mathrm{O}\end{array}$} & \multirow[t]{4}{*}{ Sh } & \multirow[t]{2}{*}{$\mathrm{Se}$} & \multirow[t]{2}{*}{$\mathrm{Hu}$} & $\begin{array}{l}\text { To stop } \\
\text { pregnancy }\end{array}$ & $\begin{array}{l}\text { Seed of Phytolacca dodecandra are crushed, smashed, squeezed } \\
\text { and the juice is drunk. }\end{array}$ & Oral \\
\hline & & & & & & Malaria & $\begin{array}{l}\text { Fresh root is smashed, mixed with water, decanted and drunk in } \\
\text { the morning. }\end{array}$ & Oral \\
\hline & & & & \multirow[t]{2}{*}{$\mathrm{R}$} & \multirow[t]{2}{*}{$\mathrm{Li}$} & Bilharziha & Fresh root is chewed and swallowed. & Oral \\
\hline & & & & & & Stomach-ache & $\begin{array}{l}\text { Fresh root is crushed and pounded with water, then filtered and } \\
\text { drunk for four days }\end{array}$ & Oral \\
\hline $\begin{array}{l}\text { Pittosporum } \\
\text { viridiflorum Sims }\end{array}$ & $\begin{array}{l}\text { Pittosporacea } \\
\text { e }\end{array}$ & $\begin{array}{l}\text { Tebera(A)Da } \\
\text { mbii(O) }\end{array}$ & $\mathrm{T}$ & $\mathrm{L}$ & $\mathrm{Hu}$ & Dandruff & $\begin{array}{l}\text { Leaf is crushed, smashed and mixed with butter and creamed after } \\
\text { having cut hair. }\end{array}$ & Dermal \\
\hline Plantago lanceolata $\mathrm{L}$. & $\begin{array}{l}\text { Plantaginacea } \\
\mathrm{e}\end{array}$ & $\begin{array}{lr}\text { Gortab } & \text { Ye } \\
\text { wusha } & \text { milas }\end{array}$ & $\mathrm{H}$ & $\mathrm{L}$ & $\mathrm{Hu}$ & Wound & $\begin{array}{l}\text { Fresh leaf of Plantago lanceolata and bulb of Allium sativum are } \\
\text { crushed, smashed together and rubbed on wounded part. }\end{array}$ & Dermal \\
\hline & & & & & & Fibril illness & Rub the body with the squeezed leaves & Dermal \\
\hline
\end{tabular}




\begin{tabular}{|c|c|c|c|c|c|c|c|c|}
\hline & & $\begin{array}{l}\text { Wenberet }(\mathrm{A}) \\
\text { Qorxobbii }(\mathrm{O}\end{array}$ & & & & Skin cut & $\begin{array}{l}\text { Fresh leaf of Plantago lanceolata is smashed, squeezed and three } \\
\text { to four drops of the exudate is added to skin cut. }\end{array}$ & Dermal \\
\hline \multirow[t]{3}{*}{$\begin{array}{l}\text { Prunus persica (L.) } \\
\text { Batsch }\end{array}$} & \multirow[t]{3}{*}{ Rosaceae } & \multirow[t]{3}{*}{$\begin{array}{l}\operatorname{Kok}(\mathrm{A}) \\
\text { Kookii }(\mathrm{O})\end{array}$} & \multirow[t]{3}{*}{$\mathrm{T}$} & $\mathrm{L}$ & $\mathrm{Hu}$ & Constipation & $\begin{array}{l}\text { Fresh leaf of Prunus persica is crushed and mixed with water and } \\
\text { given orally for continuous days until it gets relieve. }\end{array}$ & Oral \\
\hline & & & & $\mathrm{L}$ & $\mathrm{Hu}$ & Diarrhea & $\begin{array}{l}\text { Leaf is pounded, mixed with water and decanted, and then one cup } \\
\text { of local tella is given to Human. }\end{array}$ & Oral \\
\hline & & & & Ep & $\mathrm{Hu}$ & $\begin{array}{l}\text { For delayed } \\
\text { pregnancyWom } \\
\text { an( } \\
\text { Infertile) }\end{array}$ & $\begin{array}{l}\text { Leaf of epiphyte is cut by her Husband. Then crushed, mixed with } \\
\text { water, decanted, drunk at bed time and continuing sexual } \\
\text { intercourse. }\end{array}$ & Oral \\
\hline \multirow{3}{*}{$\begin{array}{l}\text { Pterolobium } \\
\text { stellatum(Forsk)Brena } \\
\mathrm{n}\end{array}$} & \multirow[t]{3}{*}{ Fabaceae } & \multirow{3}{*}{$\begin{array}{l}\text { Kentafa }(\mathrm{A}) \\
\text { Harangamaa( } \\
\text { O) }\end{array}$} & \multirow[t]{3}{*}{ Sh } & $\mathrm{L}$ & $\mathrm{Hu}$ & Goiter & $\begin{array}{l}\text { Crush the leaves and mix with butter. Then apply the paste and tie } \\
\text { it on the neck. }\end{array}$ & Dermal \\
\hline & & & & $\mathrm{L}$ & $\mathrm{Hu}$ & Evil eye & $\begin{array}{l}\text { Leaf of Pterolobium stellatem and Ruta chalepensis are pounded, } \\
\text { mixed with water and one coffee cup is drunk. }\end{array}$ & Oral \\
\hline & & & & $\mathrm{R}$ & $\mathrm{Hu}$ & Sudden sickness & $\begin{array}{l}\text { Root of Pterolobium stellatem is dried, powdered and preserved. } \\
\text { One spoon of the powder is mixed with alcohol and given to } \\
\text { human. }\end{array}$ & Oral \\
\hline \multirow{3}{*}{$\begin{array}{l}\text { Rhamnus prinoides L. } \\
\text { Herit. }\end{array}$} & \multirow[t]{3}{*}{ Rhamnaceae } & \multirow{3}{*}{$\begin{array}{l}\text { Gesho(A) } \\
\text { Geeshoo(O) }\end{array}$} & \multirow[t]{3}{*}{ Sh } & $\mathrm{L}$ & $\mathrm{Hu}$ & Teeth-ache & Leaf is chewed and kept on the teeth. & Oral \\
\hline & & & & $\mathrm{L}$ & $\mathrm{Li}$ & Leech & $\begin{array}{l}\text { Leaf is crushed, dried and soaked with the leaves of a } \\
\text { Solanumtuberosum at least for } 2 \text { days \& then given small droplets } \\
\text { through left nostril \& then much more through their mouth. }\end{array}$ & Oral and Nasal \\
\hline & & & & $\mathrm{L}$ & $\mathrm{Hu}$ & Tonsillitis & Young leaves are chewed and the juice is swallowed. & Oral \\
\hline \multirow[t]{4}{*}{ Ricinus communis L. } & \multirow[t]{4}{*}{$\begin{array}{l}\text { Euphorbiacea } \\
\text { e }\end{array}$} & \multirow[t]{4}{*}{$\begin{array}{l}\text { Gulo(A) } \\
\text { Qobboo(O) }\end{array}$} & \multirow[t]{4}{*}{ Sh } & $\mathrm{Se}$ & $\mathrm{Hu}$ & Headache & Seed is pounded, mixed with butter, and tied on head. & Dermal \\
\hline & & & & $\mathrm{Se}$ & $\mathrm{Li}$ & Anthrax & $\begin{array}{l}\text { Fresh Fruit is pounded, mixed with water and given for cattle to } \\
\text { drink. }\end{array}$ & Oral \\
\hline & & & & $\mathrm{Se}$ & $\mathrm{Hu}$ & Impotency & $\begin{array}{l}\text { Seeds are pounded, mixed with small quantity of Aloe spp. latex } \\
\text { and drink one coffee cup before bed time for } 3-4 \text { days. }\end{array}$ & Oral \\
\hline & & & & $\mathrm{L}$ & $\mathrm{Li}$ & Bloating & $\begin{array}{l}\text { Fresh leaf is pounded, mixed with water; salt is added and given } \\
\text { to cattle Orally. }\end{array}$ & Oral \\
\hline \multirow[t]{3}{*}{$\begin{array}{l}\text { Rosa abyysinica } \\
\text { Lindley }\end{array}$} & \multirow[t]{3}{*}{ Rosaceae } & \multirow[t]{3}{*}{$\begin{array}{l}\operatorname{Kega}(\mathrm{A}) \\
\operatorname{Goraa}(\mathrm{O})\end{array}$} & \multirow[t]{3}{*}{ Sh } & $\mathrm{L}$ & \multirow[t]{2}{*}{$\mathrm{Hu}$} & Ascariasis & $\begin{array}{l}\text { Fresh leaf is pounded, mixed with water and a cup of the mixture } \\
\text { is drunk. }\end{array}$ & Oral \\
\hline & & & & $\mathrm{Fu}$ & & Hypertension & $\begin{array}{l}\text { Fresh fruit with the leaves of Otostegia integrifolia are ground, } \\
\text { powdered, mixed with water and one coffee cup is drunk during } \\
\text { the sick time. }\end{array}$ & Oral \\
\hline & & & & $\begin{array}{l}\text { Fw/ } \\
\mathrm{L}\end{array}$ & & Erythroblasts & The flower and leaf of Rosa abyssinica is eaten for some days. & Oral \\
\hline \multirow[t]{2}{*}{$\begin{array}{l}\text { Rumex abyssinicus } \\
\text { Jacq. }\end{array}$} & \multirow[t]{2}{*}{ Polygonaceae } & \multirow[t]{2}{*}{$\begin{array}{l}\text { Makmako(A) } \\
\text { Dhangaggoo } \\
\text { Fardaa }(\mathrm{O})\end{array}$} & \multirow[t]{2}{*}{$\mathrm{H}$} & $\mathrm{R}$ & $\mathrm{Hu}$ & "Ayne tila" & $\begin{array}{l}\text { Root of Rumex abyssinicus and root of Verbascum sinaiticum are } \\
\text { crushed together and mixed with honey. Then drunk before } \\
\text { breakfast for three consecutive days. }\end{array}$ & Oral \\
\hline & & & & $\mathrm{R}$ & $\mathrm{Hu}$ & Hypertension & $\begin{array}{l}\text { Dried root of Rumex abyssinicus is pounded, added to tea and } \\
\text { drunk }\end{array}$ & Oral \\
\hline
\end{tabular}




\begin{tabular}{|c|c|c|c|c|c|c|c|c|}
\hline & & & & $\mathrm{R}$ & $\mathrm{Hu}$ & Ring worm & $\begin{array}{l}\text { The root of Rumex abyssinicus with root of Rumex nepalensis is } \\
\text { pounded, powdered, mixed with solution of Citrus limon and } \\
\text { creamed on affected part. }\end{array}$ & Dermal \\
\hline \multirow[t]{6}{*}{$\begin{array}{ll}\text { Rumex } \quad \text { nepalensis } \\
\text { Spreng. }\end{array}$} & \multirow[t]{6}{*}{ Polygonaceae } & \multirow[t]{6}{*}{$\begin{array}{l}\text { Lut (A) } \\
\text { Tultii(O) }\end{array}$} & \multirow[t]{6}{*}{$\mathrm{H}$} & $\mathrm{R}$ & $\mathrm{Li}$ & $\begin{array}{l}\text { Retained } \\
\text { placenta }\end{array}$ & $\begin{array}{l}\text { Latex of Rumex nepalensis root is washed out by water and given } \\
\text { to animal (e.g. sheep, cow) }\end{array}$ & Oral \\
\hline & & & & $\mathrm{R}$ & $\mathrm{Hu}$ & Stomach-ache & Root is Chewed and the sap is swallowed. & Oral \\
\hline & & & & $\mathrm{R}$ & $\mathrm{Hu}$ & Wound & Root is chopped, dried, powdered and applied on wounded part. & Dermal \\
\hline & & & & $\mathrm{L}$ & $\mathrm{Hu}$ & Spider poison & Leaf of Rumex nepalensis is directly rubbed on affected skin. & Dermal \\
\hline & & & & $\mathrm{R}$ & $\mathrm{Hu}$ & $\begin{array}{l}\text { Internal } \\
\text { Parasite }\end{array}$ & $\begin{array}{l}\text { The root is Chewed and swallowed or boiled in the water and one } \\
\text { glass of the solution is drunk. }\end{array}$ & Oral \\
\hline & & & & $\mathrm{R}$ & $\mathrm{Hu}$ & Body swelling & Dry/fresh root is chewed and put on the swollen part. & Oral \\
\hline \multirow[t]{4}{*}{ Rumexnervosus Vahl } & \multirow[t]{4}{*}{ Polygonaceae } & \multirow[t]{4}{*}{$\begin{array}{l}\text { Embacho }(\mathrm{A}) \\
\text { Dhangaggoo }\end{array}$} & \multirow[t]{4}{*}{ Sh } & $\mathrm{L}$ & $\mathrm{Hu}$ & Wound & $\begin{array}{l}\text { Dried root bark is crushed, pounded, mixed with butter and placed } \\
\text { on the wound. }\end{array}$ & Dermal \\
\hline & & & & $\mathrm{R}$ & & Skin rash & $\begin{array}{l}\text { Root of Rumex nervosus is dried and powdered. One coffee cup of } \\
\text { powder is mixed with butter and creamed on affected skin }\end{array}$ & Dermal \\
\hline & & & & $\mathrm{L}$ & $\mathrm{Hu}$ & Snake bite & $\begin{array}{l}\text { The leaf of Rumex nervosus is chewed and the solution is } \\
\text { swallowed during bite time. }\end{array}$ & Oral \\
\hline & & & & $\mathrm{L} / \mathrm{St}$ & $\mathrm{Li}$ & Lice & $\begin{array}{l}\text { Rumex nervosus together with Sida schimperiana is used to wash } \\
\text { the calf to remove external parasites and Scabies (itches). }\end{array}$ & Dermal \\
\hline \multirow[t]{3}{*}{ Ruta chalepensis L. } & \multirow[t]{3}{*}{ Rutaceae } & \multirow{3}{*}{$\begin{array}{l}\text { Tenadam }(\mathrm{A}) \\
\text { Cilaattama }(\mathrm{O})\end{array}$} & \multirow[t]{3}{*}{$\mathrm{H}$} & $\mathrm{L}$ & $\mathrm{Hu}$ & Stomach-ache & $\begin{array}{l}\text { Fresh leaf of Ruta chalepensis mixed with sugar \& powder of } \\
\text { Vicia faba, then boiled and drunk (or chewing and taking the sap). }\end{array}$ & Oral \\
\hline & & & & $\mathrm{B} / \mathrm{L}$ & $\mathrm{Li}$ & $\begin{array}{l}\text { Cocoidiosis } \\
\text { (Bilii) }\end{array}$ & $\begin{array}{l}\text { Bark and leaf of Ruta chalepensis and root of Justica } \\
\text { schimperiana are pounded together and given to hen with injera. }\end{array}$ & Oral \\
\hline & & & & $\mathrm{Se}$ & $\mathrm{Hu}$ & Evil eye & $\begin{array}{l}\text { The seed of Ruta chalepensis with Allium sativum are finely } \\
\text { crushed together and sniffed at the sickness time }\end{array}$ & Nasal \\
\hline \multirow[t]{3}{*}{$\begin{array}{l}\text { Salix } \quad \text { macronata } \\
\text { THunb. }\end{array}$} & \multirow[t]{3}{*}{ Salicaceae } & \multirow[t]{3}{*}{$\begin{array}{l}\text { Lahaya(A) } \\
\text { Alaltuu(O) }\end{array}$} & \multirow[t]{3}{*}{$\mathrm{T}$} & Sht & $\mathrm{Hu}$ & Hemorrhage & $\begin{array}{l}\text { Fresh shoot is crushed, squeezed and the juice is rubbed on the } \\
\text { affected part. }\end{array}$ & Oral \\
\hline & & & & $\mathrm{L}$ & $\mathrm{Hu}$ & Wound & $\begin{array}{l}\text { Fresh leaf of Salix macronata is pounded and placed on wounded } \\
\text { part }\end{array}$ & Dermal \\
\hline & & & & $\mathrm{L}$ & $\mathrm{Li}$ & Joint dislocation & $\begin{array}{l}\text { The leaf is ground along with young stem, mixed with bread and } \\
\text { given to the cattle in problem }\end{array}$ & Oral \\
\hline \multirow[t]{2}{*}{ Schinus molle L. } & \multirow{2}{*}{$\begin{array}{l}\text { Anacardiacea } \\
\text { e }\end{array}$} & \multirow{2}{*}{$\begin{array}{l}\text { Kundoberbere } \\
\text { (A) } \\
\text { Qundobarbare } \\
\text { e(O) }\end{array}$} & \multirow[t]{2}{*}{$\mathrm{T}$} & $\mathrm{L} / \mathrm{Fu}$ & $\mathrm{Li}$ & Eye disease & $\begin{array}{l}\text { Fesh Leaf and fruit of Schinusmolle are chewed and spitted on } \\
\text { cattle, equines, goat and sheep eye. }\end{array}$ & Eye \\
\hline & & & & $\mathrm{Se}$ & $\mathrm{Hu}$ & Tonsillitis & $\begin{array}{l}\text { Dried seed of Schinusmolle is pounded, powdered, mixed with } \\
\text { honey and then drunk }\end{array}$ & Oral \\
\hline Sesamum indicum L. & Pedaliaceae & $\begin{array}{l}\text { Selit(A) } \\
\text { Saliixa(O) }\end{array}$ & $\mathrm{H}$ & $\mathrm{Se}$ & $\mathrm{Hu}$ & Ear defect & Extract oil from the seed and drop the extract in canal the ear. & Ear \\
\hline \multirow[t]{3}{*}{$\begin{array}{l}\text { Sidas chimperiana } \\
\text { Hochst. Ex A. Rich. }\end{array}$} & \multirow[t]{3}{*}{ Malavaceae } & \multirow[t]{3}{*}{$\begin{array}{l}\text { Cifrig }(\mathrm{A}) \\
\text { Harmellaa }(\mathrm{O})\end{array}$} & \multirow[t]{3}{*}{$\mathrm{H}$} & $\mathrm{R}$ & $\mathrm{Hu}$ & Syphilis (ketegn) & $\begin{array}{l}\text { Fresh Root of Sidaschimperiana and root of Solanumadoense are } \\
\text { crushed together and mixed with water and decanted. Then mixed } \\
\text { with honey and drunk. }\end{array}$ & Oral \\
\hline & & & & $\mathrm{R}$ & $\mathrm{Li}$ & Horse disease & $\begin{array}{l}\text { Ground, mixed with water and drunk or applied through the } \\
\text { nostrils. }\end{array}$ & Nasal \\
\hline & & & & $\mathrm{R}$ & $\mathrm{Hu}$ & Evil eye & Root is fumigated every evening to patient until recovery. & Nasal \\
\hline
\end{tabular}




\begin{tabular}{|c|c|c|c|c|c|c|c|c|}
\hline \multirow{3}{*}{$\begin{array}{l}\text { Solanum adoense } \\
\text { (Hochst) ex A. Rich. }\end{array}$} & \multirow[t]{3}{*}{ Solanaceae } & \multirow{3}{*}{$\begin{array}{l}\text { Zerch } \\
\text { Enbuay(A) } \\
\text { Hiddii } \\
\text { baddaa(O) }\end{array}$} & \multirow[t]{3}{*}{ Sh } & $\mathrm{Fu}$ & $\mathrm{Hu}$ & Wound & Adding the drop of Solanum adoense fruit juice on wounded part & Dermal \\
\hline & & & & $\mathrm{Fu}$ & $\mathrm{Li}$ & Bloat & Fruits of Solanumadoense are Squeezed on cattle feed. & Oral \\
\hline & & & & $\mathrm{L}$ & $\mathrm{Li}$ & Anthrax & $\begin{array}{l}\text { Dried leaf of Solanum adoense is crushed, pounded, mixed with } \\
\text { tella and given to cattle. }\end{array}$ & Oral \\
\hline \multirow[t]{4}{*}{ Solanum incanum L. } & \multirow[t]{4}{*}{ Solanaceae } & \multirow{4}{*}{$\begin{array}{l}\text { Enbuay(A) } \\
\text { Hiddii } \\
\text { loonii(O) }\end{array}$} & \multirow[t]{4}{*}{$\mathrm{Sh}$} & $\mathrm{R}$ & $\mathrm{Hu}$ & Snake bite & Dried root powder is drunk with coffee. & Oral \\
\hline & & & & $\mathrm{Sa}$ & $\mathrm{Hu}$ & $\begin{array}{l}\text { Infection caused } \\
\text { by spine in leg }\end{array}$ & The sap of fresh fruit is squeezed \& dropped on affected part. & Dermal \\
\hline & & & & $\mathrm{L}$ & $\mathrm{Hu}$ & Nasal bleeding & $\begin{array}{l}\text { The leaf of Solanum incanum is ground, powdered and sniffed } \\
\text { several times until recovery. }\end{array}$ & Nasal \\
\hline & & & & $\mathrm{L}$ & $\mathrm{Li}$ & $\begin{array}{l}\text { Urination } \\
\text { problem }\end{array}$ & $\begin{array}{l}\text { The leaf of Solanum incanum and that of Cuminum cyminum are } \\
\text { smashed together, mixed with water and given for horse, donkey, } \\
\text { and mules to drink }\end{array}$ & Oral \\
\hline \multirow[t]{2}{*}{$\begin{array}{l}\text { Solanecio gigas } \\
\text { (Vatke.)C. Jeffery }\end{array}$} & \multirow[t]{2}{*}{ Astraceae } & \multirow{2}{*}{$\begin{array}{l}\text { Yeshikoko } \\
\text { gomen(Mogn } \\
\text { e qitel(A)) } \\
\text { Jirma } \\
\text { Jaldeessaa(O) }\end{array}$} & \multirow[t]{2}{*}{ Sh } & $\mathrm{L}$ & $\mathrm{Li}$ & Bloating & $\begin{array}{l}\text { The leaf of Solanecio gigas is pounded, squeezed and the juice is } \\
\text { added through the nose }\end{array}$ & Nasal \\
\hline & & & & $\mathrm{L}$ & $\mathrm{Li}$ & Lice & Leaf of Solanecio gigas is used to wash hair of calf as lice killer. & Dermal \\
\hline \multirow[t]{3}{*}{$\begin{array}{l}\text { Stephania abyssinica } \\
\text { (Dillo\&A.Rich.)Walp. }\end{array}$} & \multirow[t]{3}{*}{$\begin{array}{l}\text { Menispermac } \\
\text { ae }\end{array}$} & \multirow{3}{*}{$\begin{array}{l}\text { Ye ayit hareg( } \\
\text { Chewchawit( } \\
\text { Etse } \\
\text { Iyesus(A) } \\
\text { Hidda } \\
\text { kalaalaa(O) }\end{array}$} & \multirow[t]{3}{*}{$\mathrm{Cl}$} & $\mathrm{L}$ & $\mathrm{Hu}$ & Wound & $\begin{array}{l}\text { Leaf of Stephania abyssinica is pounded and a small amount is } \\
\text { added to wound. }\end{array}$ & Dermal \\
\hline & & & & $\mathrm{R}$ & $\mathrm{Li}$ & Rabies & $\begin{array}{l}\text { Dry root of Stephaniaabyssinica is powdered and baked with teff } \\
\text { flour and given to cattle. }\end{array}$ & Oral \\
\hline & & & & $\mathrm{L}$ & $\mathrm{Li}$ & Pasturolosis & $\begin{array}{l}\text { Dried root and leaf of Stephaniaabyssinica is powdered together, } \\
\text { mixed with water and given to the animal (cattle, goat or sheep). }\end{array}$ & Oral \\
\hline \multirow[t]{2}{*}{$\begin{array}{l}\text { Syzgium aromaticum } \\
\text { L. }\end{array}$} & \multirow[t]{2}{*}{ myrtaceae } & \multirow{2}{*}{$\begin{array}{l}\text { Kirunfud(A) } \\
\text { Qurunfudii(O }\end{array}$} & \multirow[t]{2}{*}{$\mathrm{T}$} & $\mathrm{Fu}$ & $\mathrm{Hu}$ & Impotency & $\begin{array}{l}\text { Dried Syzgium aromaticum is crushed, mixed with goat milk and } \\
\text { boiled. Then the decoction is drunk. }\end{array}$ & Oral \\
\hline & & & & $\mathrm{Fu}$ & $\mathrm{Hu}$ & Vomit & $\begin{array}{l}\text { Fruit of Syzgiumaromaticum with rhizome of Zingiberofficinale is } \\
\text { boiled and drunk. }\end{array}$ & Oral \\
\hline $\begin{array}{l}\text { Tanacetum } \\
\text { cinerariifolium (Trev). } \\
\text { Sch. Bip. }\end{array}$ & Asteraceae & Kaba(A) & $\mathrm{H}$ & $\mathrm{L}$ & $\mathrm{Hu}$ & Fibril illness & The leaf of Tanacetum cineratiifolium is squeezed and drunk & Oral \\
\hline \multirow[t]{3}{*}{$\begin{array}{l}\text { Trigonellafoenum- } \\
\text { Graecum L. }\end{array}$} & \multirow[t]{3}{*}{ Fabaceae } & \multirow[t]{3}{*}{$\begin{array}{l}\text { Abish(A) } \\
\text { Sunqoo(O) }\end{array}$} & \multirow[t]{3}{*}{$\mathrm{H}$} & $\mathrm{Se}$ & $\mathrm{Hu}$ & Leg wound & $\begin{array}{l}\text { Seed of TrigonellafoenumGraecum, seed of Faciafaba and seed of } \\
\text { Linumusitatissimum are finely ground together, rolled in piece of } \\
\text { cloth and tied on leg }\end{array}$ & Dermal \\
\hline & & & & $\mathrm{Se}$ & $\mathrm{Hu}$ & Body swelling & $\begin{array}{l}\text { The seed of Trigonellafoenum-graecum is crushed, powdered, } \\
\text { mixed with honey and little water, then boiled like "porage" and } \\
\text { eaten }\end{array}$ & Oral \\
\hline & & & & $\mathrm{Se}$ & $\mathrm{Hu}$ & Bone fracture & $\begin{array}{l}\text { Seed is powdered; water is added to flour to make the paste, and } \\
\text { then applied to the broken bone. }\end{array}$ & Oral \\
\hline \multirow[t]{3}{*}{$\begin{array}{ll}\text { Thymus } & \text { schimperi } \\
\text { Ronniger }\end{array}$} & \multirow[t]{3}{*}{ Lamiaceae } & \multirow[t]{3}{*}{$\begin{array}{l}\text { Tosign }(A) \\
\text { Xassee }(O)\end{array}$} & \multirow[t]{3}{*}{$\mathrm{H}$} & $\mathrm{Ag}$ & $\mathrm{Hu}$ & Cough & $\begin{array}{l}\text { Its leaves, root and bark are ground together, powdered and mixed } \\
\text { with water, one coffee cup (sini) is drunk during pain time. }\end{array}$ & Oral \\
\hline & & & & $\mathrm{L}$ & $\mathrm{Hu}$ & Stomach-ache & $\begin{array}{l}\text { Leaf is boiled with leaves of Foeniculumvulgare and one tea cup } \\
\text { is taken. }\end{array}$ & Ora \\
\hline & & & & $\mathrm{L}$ & $\mathrm{Hu}$ & Hypertension & Leaf is boiled with sugar and drunk. & Oral \\
\hline
\end{tabular}




\begin{tabular}{|c|c|c|c|c|c|c|c|c|}
\hline $\begin{array}{l}\text { Urera hypselodendron } \\
\text { (A. Rich.) Wedd. }\end{array}$ & Urticaceae & $\begin{array}{l}\text { Lankuso(A) } \\
\text { Laanqisaa } \\
\text { dhoqonu }(\mathrm{O}) \\
\end{array}$ & $\mathrm{Cl}$ & $\mathrm{B}$ & $\mathrm{Li}$ & Anthrax & $\begin{array}{l}\text { Bark/shoot of Urera hypselodendron is crushed, smashed, mixed } \\
\text { with powder of Trigonella } \\
\text { foenum-graecum or with egg and given to cattle. }\end{array}$ & Oral \\
\hline \multirow[t]{2}{*}{$\begin{array}{l}\text { Urtica } \\
\text { Steudel }\end{array}$} & \multirow[t]{2}{*}{ Urticaceae } & \multirow[t]{2}{*}{$\begin{array}{l}\text { Sama(A) } \\
\text { Doobbii (O) }\end{array}$} & \multirow[t]{2}{*}{$\mathrm{H}$} & $\mathrm{L}$ & $\mathrm{Hu}$ & $\begin{array}{l}\text { Gastritis, Heart } \\
\text { Disease }\end{array}$ & Eat in the form of stew ('wot') against gastritis \& heart disease. & Oral \\
\hline & & & & $\mathrm{R} / \mathrm{L}$ & $\mathrm{Hu}$ & Gonorrhea & $\begin{array}{l}\text { The root and leaves of Urticasimensis with the bark of } \\
\text { Crotonmacrostachyhus are pounded, powdered, mixed with little } \\
\text { water, filtered, then a cup of filtrate is drunk for } 5 \text { days in the } \\
\text { morning }\end{array}$ & Oral \\
\hline \multirow[t]{3}{*}{ Verbena officinalis L. } & \multirow[t]{3}{*}{ Verbenaceae } & \multirow[t]{3}{*}{$\begin{array}{l}\text { Atuch(A) } \\
\operatorname{Derguu}(\mathrm{O})\end{array}$} & \multirow[t]{3}{*}{$\mathrm{H}$} & $\mathrm{L}$ & $\mathrm{Hu}$ & For tonsillitis & $\begin{array}{l}\text { Leaf of Verbenaofficinalis is Crushed, smashed, mixed with butter } \\
\text { and creamed around neck. }\end{array}$ & Dermal \\
\hline & & & & $\mathrm{R}$ & $\mathrm{Hu}$ & Fibril illness & $\begin{array}{l}\text { Root of Verbenaofficinalis, together with the root of } \\
\text { Carissaspinarum and root of Rutachalepensis, are fumigated to } \\
\text { the patient. }\end{array}$ & Nasal \\
\hline & & & & $\mathrm{R}$ & $\mathrm{Hu}$ & Diarrhea & $\begin{array}{l}\text { Root of } V \text {. officinalis and root of Phytolaccadodecandra, bark of } \\
\text { Crotonmacrostachyus are pounded, mixed with water, decanted } \\
\text { and drunk after a day. }\end{array}$ & Dermal \\
\hline \multirow[t]{3}{*}{$\begin{array}{l}\text { Verbascum sinaiticum } \\
\text { Benth. }\end{array}$} & \multirow[t]{3}{*}{$\begin{array}{l}\text { Scrophulariac } \\
\text { eae }\end{array}$} & \multirow{3}{*}{$\begin{array}{l}\text { Kutina( } \\
\text { Ye Ahya } \\
\text { joro(A) } \\
\text { Gurra Harree } \\
\text { (O) }\end{array}$} & \multirow[t]{3}{*}{$\mathrm{H}$} & $\mathrm{R}$ & $\mathrm{Li}$ & Horse disease & $\begin{array}{l}\text { Fresh Root of Verbascumsinaiticum is collected from three places, } \\
\text { smashed, mixed with water, decanted and given to horse }\end{array}$ & Oral \\
\hline & & & & $\mathrm{L}$ & $\mathrm{Hu}$ & Impotency & $\begin{array}{l}\text { Chopped Leaf of Verbascum sinaiticum is rolled by clean piece } \\
\text { of cloth and tied around male sex organ to erect it. }\end{array}$ & Dermal \\
\hline & & & & $\mathrm{R}$ & $\mathrm{Hu}$ & Wound & $\begin{array}{l}\text { The root of Verbascum sinaiticum is crushed, powdered, mixed } \\
\text { with butter and creamed on affected part. }\end{array}$ & Dermal \\
\hline \multirow[t]{3}{*}{$\begin{array}{l}\text { Vernonia amygdalina } \\
\text { Del. }\end{array}$} & \multirow[t]{3}{*}{ Asteraceae } & \multirow[t]{3}{*}{$\begin{array}{l}\text { Gerawa }(\mathrm{A}) \\
\text { Eebicha }(\mathrm{O})\end{array}$} & \multirow[t]{3}{*}{$\mathrm{T}$} & $\mathrm{L}$ & $\mathrm{Hu}$ & Malaria & $\begin{array}{l}\text { Crushed leaves of Vernonia amygdalina concocted with leaves of } \\
\text { Ruta chalepensis. One cup is served as a drink for 3-5 days with } \\
\text { cold water in the morning. }\end{array}$ & Oral \\
\hline & & & & $\mathrm{L}$ & $\mathrm{Hu}$ & Skin infection & $\begin{array}{l}\text { The leaf of Vernonia amygdalina is pounded and the patient body } \\
\text { is washed by the plant or the leaf of is used as a soap to wash the } \\
\text { infected body. }\end{array}$ & Dermal \\
\hline & & & & $\mathrm{L}$ & $\mathrm{Li}$ & $\begin{array}{l}\text { Bloating } \\
\text { Urine retention }\end{array}$ & $\begin{array}{l}\text { Fresh leaves is squeezed, mixed with water, and then given to } \\
\text { cattle in morning and at night until recovery. }\end{array}$ & Oral \\
\hline \multirow[t]{2}{*}{$\begin{array}{l}\text { Vernonia hymenolepis } \\
\text { A.Rich. }\end{array}$} & \multirow[t]{2}{*}{ Asteraceae } & \multirow[t]{2}{*}{$\begin{array}{l}\text { Weynagift }(\mathrm{A}) \\
\text { Sooyyama }(\mathrm{O})\end{array}$} & \multirow[t]{2}{*}{$\mathrm{Sh}$} & $\mathrm{L}$ & $\mathrm{Hu}$ & Gonorrhea & $\begin{array}{l}\text { Leaf twig of Vernonia hymenolepis and bark of Croton } \\
\text { macrostachyus are pounded together, mixed with honey and 1-3 } \\
\text { spoons is taken in the morning before breakfast. }\end{array}$ & Oral \\
\hline & & & & $\mathrm{L}$ & $\mathrm{Hu}$ & Wound & $\begin{array}{l}\text { Leaf of Vernonia hymenolepis is squeezed and the sap is dropped } \\
\text { on the wound. }\end{array}$ & Dermal \\
\hline \multirow[t]{4}{*}{$\begin{array}{l}\text { Zehneria scabra } \\
\text { (Linn.f.) Sond. }\end{array}$} & \multirow[t]{4}{*}{ Cucurbitaceae } & \multirow{4}{*}{$\begin{array}{l}\text { Haregresa( } \\
\text { Etse sabeq( } \\
\text { Nech } \\
\text { Hareg(A) } \\
\text { Qorii } \\
\text { Sinbiraa(O) }\end{array}$} & \multirow[t]{4}{*}{$\mathrm{Cl}$} & $\mathrm{L}$ & $\mathrm{Hu}$ & Swelling & $\begin{array}{l}\text { Leaf and bark of Zehneria scabra and leaf of Rumex nervosues are } \\
\text { pounded together, rolled in clean cloth, and tied on swelling. }\end{array}$ & Dermal \\
\hline & & & & $\mathrm{L}$ & $\mathrm{Hu}$ & Fibril illness & $\begin{array}{l}\text { The leaf of Zehneria scabra is pounded, squeezed and mixed with } \\
\text { sugar and drunk one cup /or the stem is boiled and inhaled }\end{array}$ & Oral \\
\hline & & & & $\mathrm{R}$ & $\mathrm{Hu}$ & Sudden sicknes & Fresh root is pounded, mixed with water and drunk. & Oral \\
\hline & & & & $\mathrm{L}$ & $\mathrm{Hu}$ & Dandruff & Fresh leaf is squeezed to make juice and creamed after hair is cut. & Dermal \\
\hline
\end{tabular}




\begin{tabular}{|c|c|c|c|c|c|c|c|c|}
\hline $\begin{array}{l}\text { Ziziphus spina- christi } \\
\text { (L.) Desf. }\end{array}$ & Rhamnaceae & $\operatorname{Gaba}(\mathrm{A})$ & Sh & $\mathrm{L}$ & $\mathrm{Hu}$ & Dandruff & $\begin{array}{l}\text { The leaf of Zizlphus spina-christi is pounded, powdered, mixed } \\
\text { with butter and then creamed. }\end{array}$ & Dermal \\
\hline \multirow[t]{2}{*}{$\begin{array}{l}\text { Zingiber officinale } \\
\text { Roscoe }\end{array}$} & \multirow[t]{2}{*}{ Zingiberaceae } & \multirow[t]{2}{*}{$\begin{array}{l}\text { Jinjible(A) } \\
\text { Zinjibila(O) }\end{array}$} & \multirow[t]{2}{*}{$\mathrm{H}$} & \multirow[t]{2}{*}{$\mathrm{Rh}$} & $\mathrm{Hu}$ & Malaria & $\begin{array}{l}\text { Rhizome of Zingiber officinale and bulb of Allium sativum are } \\
\text { pounded together and eaten with honey. }\end{array}$ & Oral \\
\hline & & & & & $\mathrm{Hu}$ & Stomach ache & $\begin{array}{l}\text { Rhizome of Zingiber officinale together with Leaf of Vernonia } \\
\text { amygdalina and bulb of Allium sativum are pounded and eaten } \\
\text { with honey. }\end{array}$ & Oral \\
\hline
\end{tabular}


Appendix 3: List of the medicinal plant families and corresponding number of genera and species in the study area

\begin{tabular}{|c|c|c|c|c|c|c|c|}
\hline No. & Family & No. of genera & $\begin{array}{l}\text { No. of plant } \\
\text { species }\end{array}$ & No & Family & $\begin{array}{l}\text { No. of } \\
\text { genera }\end{array}$ & $\begin{array}{ll}\text { No. } & \text { of } \\
\text { plant } & \\
\text { species } & \end{array}$ \\
\hline 1. & Acanthaceae & 1 & 1 & 27 & Menispermacae & 1 & 1 \\
\hline 2. & Alliaceae & 1 & 2 & 28 & Myrsinaceae & 2 & 2 \\
\hline 3. & Aloaceae & 1 & 1 & 29 & Myrtaceae & 3 & 3 \\
\hline 4. & Amaranthaceae & 1 & 1 & 30 & Oleaceae & 2 & 2 \\
\hline 5. & Anacardiaceae & 1 & 1 & 31 & Pedaliaceae & 1 & 1 \\
\hline 6. & Apiaceae & 1 & 1 & 32 & Phytolaccaceae & 1 & 1 \\
\hline 7. & Apocynaceae & 1 & 1 & 33 & Pittosporaceae & 1 & 1 \\
\hline 8. & Asparagacea & 1 & 1 & 34 & Plantaginaceae & 1 & 1 \\
\hline 9. & Asteraceae & 6 & 7 & 35 & Polygonaceae & 1 & 3 \\
\hline 10. & Boraginaceae & 2 & 2 & 36 & Ranunculaceae & 2 & 2 \\
\hline 11. & Brassicaceae & 2 & 3 & 37 & Rhamnaceae & 2 & 2 \\
\hline 12. & Cactaceae & 1 & 1 & 38 & Rosaceae & 3 & 3 \\
\hline 13. & Caricaceae & 1 & 1 & 39 & Rubiaceae & 1 & 1 \\
\hline 14. & Cucurbitaceae & 3 & 3 & 40 & Rutaceae & 2 & 2 \\
\hline 15. & Cupressaceae & 2 & 2 & 41 & Salicaceae & 1 & 1 \\
\hline 16. & Ericaceae & 1 & 1 & 42 & Santalaceae & 1 & 1 \\
\hline 17. & Euphorbiaceae & 5 & 5 & 43 & Sapindaceae & 1 & 1 \\
\hline 18. & Fabaceae & 4 & 4 & 44 & Scrophulariaceae & 1 & 1 \\
\hline 19. & Flacourtiaceae & 1 & 1 & 45 & Simaroubaceae & 1 & 1 \\
\hline 20. & Hypericaceae & 1 & 1 & 46 & Solanaceae & 5 & 6 \\
\hline 21. & Lamiaceae & 4 & 5 & 47 & Sterculiaceae & 1 & 1 \\
\hline 22. & Lineaceae & 1 & 1 & 48 & Urticaceae & 2 & 2 \\
\hline 23. & Lobeliaceae & 1 & 1 & 49 & Verbenaceae & 1 & 1 \\
\hline 24. & Loganiaceae & 1 & 1 & 50 & Vitaceae & 1 & 1 \\
\hline 25. & Malvaceae & 2 & 2 & 51 & Zingiberaceae & 1 & 1 \\
\hline 26. & Meliaceae & 1 & 1 & & & & \\
\hline & & & & & & & \\
\hline
\end{tabular}

Appendix 4: List of human diseases in the study area

\begin{tabular}{|c|c|c|c|}
\hline No & Disease treated & $\begin{array}{l}\text { Total of plant species } \\
\text { used }\end{array}$ & Total percentage (\%) \\
\hline 1. & Wound & 25 & 26.88 \\
\hline 2. & Malaria & 14 & 15.05 \\
\hline 3. & Stomach-ache & 13 & 13.97 \\
\hline 4. & Body swelling andEvil eye & 10 & 10.75 \\
\hline 5. & Tonsillitis & 9 & 9.68 \\
\hline 6. & Fibril illness, Scabies(itches) and Skin rash & 7 & 7.52 \\
\hline 7. & Cough,dandruff, diarrhea and headache & 6 & 6.45 \\
\hline 8. & $\begin{array}{l}\text { Eye disease, gonorrhea, intestinal parasites and tape } \\
\text { worm }\end{array}$ & 5 & 5.38 \\
\hline 9. & Snake bite & 4 & 4.30 \\
\hline 10. & $\begin{array}{l}\text { Amoeba,bone fracture, fire burn, hypertension, } \\
\text { impotency, rabies,skin cut, sudden sickness } \\
\text { andtoothache }\end{array}$ & 3 & 3.22 \\
\hline 11. & $\begin{array}{l}\text { Asthma, cancer , heart disease, hemorrhoids ,nasal } \\
\text { bleeding, pneumonia, ring worms , urination problem } \\
\text { and vomit }\end{array}$ & 2 & 2.15 \\
\hline 12. & $\begin{array}{l}\text { Abortion( To stop pregnancy),back pain, bilharzia, ear } \\
\text { defect, goiter,infertility, retained placenta and syphilis }\end{array}$ & 1 & 1.07 \\
\hline
\end{tabular}




\begin{tabular}{|c|c|c|c|c|}
\hline No. & Disease treated & $\begin{array}{ll}\begin{array}{l}\text { Local } \\
\text { oromoo) }\end{array} & \text { name(Afaan } \\
\end{array}$ & No. of plant species used & Percent (\%) \\
\hline 1 & Bloating & Dhitahuu garraa & 10 & 10.75 \\
\hline 2 & Anthrax and & Abasanga Alekit & 6 & 6.45 \\
\hline 4 & Ectoparasite (lice) & Ye wech tegegna & 5 & 5.38 \\
\hline 5 & Rabies & Dhukkubaa sarre & 3 & 3.22 \\
\hline 6 & $\begin{array}{l}\text { Erythroblasts, horse disease, } \\
\text { retained placenta , cocoidiosis }\end{array}$ & $\begin{array}{l}\text { Machangaf ,Dhukkuba } \\
\text { fardaa,yengdelej sizegey } \\
\text { and Dhukubaa indaqoo }\end{array}$ & 2 & 2.15 \\
\hline 7 & $\begin{array}{l}\text { Blackleg, horse itch,pasturolosis and } \\
\text { eye disease }\end{array}$ & $\begin{array}{l}\text { Abagorba, Epizootic } \\
\text { lymphagities, Gororsa, } \\
\text { Aynebesheta }\end{array}$ & 1 & 1.07 \\
\hline
\end{tabular}

Appendix 6: Some of the cultivated and wild grown medicinal plants widely traded in the market for different uses in addition to medicinal values in Wonch district.

\begin{tabular}{|c|c|c|c|}
\hline № & Scientific Name of the medicinal plant & $\begin{array}{ll}\begin{array}{l}\text { Local } \\
\text { oromo) }\end{array} & \text { name(Afan } \\
\end{array}$ & Used for \\
\hline 1. & Allium cepa & Shinkurt dimma & Spice, food \\
\hline 2. & Allium sativum & Nech shinkurt & Spice,food \\
\hline 3. & Artemisia abyssinica & Harit & spice \\
\hline 4. & Brassica carinata & Gomenzer & food \\
\hline 5. & Brassica nigra & Senafich & food \\
\hline 6. & Capsicum annuum & Berbere & food \\
\hline 7. & Carica papaya & Papaya & food \\
\hline 8. & Citrus limon & Lomi & Food, \\
\hline 9. & Coffea Arabica & Buna & stimulant \\
\hline 10. & Cordia africana & Wanza & Timber,live fence, fire wood \\
\hline 11. & Coriandrum sativum & Denbelal & Food \\
\hline 12. & Croton macrostchyus & Bakanisaa(bisana) & Fire wood, \\
\hline 13. & Cucurbita pepo & Duba & Food \\
\hline 14. & Echinops kebericho & Kerebicho & Smell \\
\hline 15. & Eucalyptus globulus & Bahirzaf Addii. & Construction,fire wood, live fence \\
\hline 16. & Guizotia abyssinica & Nug & Food \\
\hline 17. & Linum usitatissimum & Telba & Food \\
\hline 18. & Lepidium sativum & Feto & Food \\
\hline 19. & Nigella sativa & Tikur azmud & Food \\
\hline 20. & Ocimum basilicum & Zikakibe & Spice \\
\hline 21. & Olea europaea L. subsp. cuspidata & Weyra & Fire wood,consruction, farming tool \\
\hline 22. & Otostegia integrifolia & Tunjit & Fumigate \\
\hline 23. & Prunus persica & Kok & Food \\
\hline 24. & Rhamnus prinoides & Gesho & Bevarage \\
\hline 25. & Ruta chalepensis & Tenadam & Spice \\
\hline 26. & Schinus molle & Kundo berbere & Spice \\
\hline 27. & Sesamum indicum & Seli & Food \\
\hline 28. & Trigonella foenum-Graecum & (Sunqoo)Abish & Food \\
\hline 29. & Thymus schimperi & Tosign & Stimulant \\
\hline 30. & Zingiber officinale & Jinjiblaa & Spice \\
\hline
\end{tabular}

